\title{
Leadership experiences,
} labor market entry, and early career trajectories

\author{
Martin Lundin \\ Oskar Nordström Skans \\ Pär Zetterberg
}


The Institute for Evaluation of Labour Market and Education Policy (IFAU) is a research institute under the Swedish Ministry of Employment, situated in Uppsala. IFAU's objective is to promote, support and carry out scientific evaluations. The assignment includes: the effects of labour market and educational policies, studies of the functioning of the labour market and the labour market effects of social insurance policies. IFAU shall also disseminate its results so that they become accessible to different interested parties in Sweden and abroad.

IFAU also provides funding for research projects within its areas of interest. The deadline for applications is October 1 each year. Since the researchers at IFAU are mainly economists, researchers from other disciplines are encouraged to apply for funding.

IFAU is run by a Director-General. The institute has a scientific council, consisting of a chairman, the Director-General and five other members. Among other things, the scientific council proposes a decision for the allocation of research grants. A reference group including representatives for employer organizations and trade unions, as well as the ministries and authorities concerned is also connected to the institute.

Postal address: P.O. Box 513, 75120 Uppsala

Visiting address: Kyrkogårdsgatan 6, Uppsala

Phone: +4618 4717070

Fax: +4618471 7071

ifau@ifau.uu.se

www.ifau.se

Papers published in the Working Paper Series should, according to the IFAU policy, have been discussed at seminars held at IFAU and at least one other academic forum, and have been read by one external and one internal referee. They need not, however, have undergone the standard scrutiny for publication in a scientific journal. The purpose of the Working Paper Series is to provide a factual basis for public policy and the public policy discussion.

ISSN 1651-1166 


\title{
Leadership experiences, labor market entry, and early career trajectories ${ }^{a}$
}

\author{
by \\ Martin Lundin ${ }^{\mathrm{b}}$, Oskar Nordström Skans ${ }^{\mathrm{c}}$ and Pär Zetterberg ${ }^{\mathrm{d}}$
}

January 22, 2016

\begin{abstract}
We study how leadership experiences before labor market entry affect subsequent labor market performance, using a regression discontinuity design to isolate the causal effects. The design is applied to elections of representatives at Swedish student union (SU) councils. Archive data on winning and losing candidates at three major Swedish universities are mapped to register data on their subsequent labor market careers. The results show that students who acquired a position in the SU councils are more likely to have a rapid transition into employment than candidates who just missed getting to get such a leadership role. The employment effects are not confined to workplaces, organizations, or industries where previous candidates are employed, suggesting that the benefits of having been a student representative are general in nature. Elected representatives are more likely to hold a well-paid job within three years, but not thereafter. Overall, our estimates suggest that leadership experiences before labor market entry boost individuals' initial career trajectories, whereas mid-term outcomes appear unaffected.
\end{abstract}

Keywords: Leadership experiences, extracurricular activities, labor market entry, earnings, higher education, non-cognitive skills

JEL-codes: I26, I23, J24

\footnotetext{
${ }^{a}$ We thank Eric Bettinger, Marcus Eliason, Erik Grönqvist, Georg Graetz, and Heléne Lundqvist as well as seminar participants at IFAU in Uppsala, SOFI at Stockholm University, and at the SOLE/EALE conference 2015 for helpful comments and suggestions. Special thanks to Cecilia Josefsson and Neshat Alizadeh Ebadi for excellent research assistance, and to the student unions for giving us access to their archives. The authors are equal contributors to this paper: names are listed in alphabetical order.

IFAU; e-mail: martin.lundin@ifau.uu.se

c Department of Economics, Uppsala University; e-mail: oskar.nordstrom_skans@nek.uu.se

d Department of Government, Uppsala University; e-mail: par.zetterberg@statsvet.uu.se
} 


\section{Table of contents}

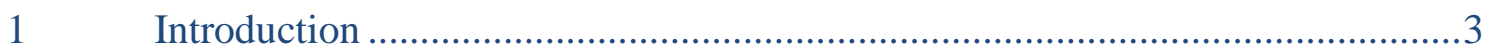

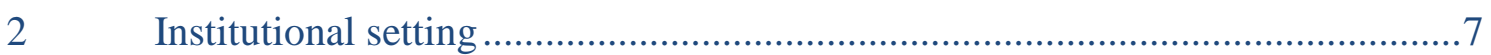

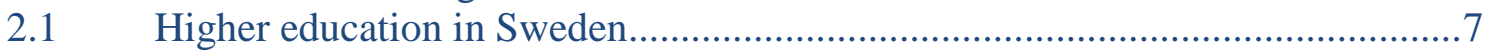

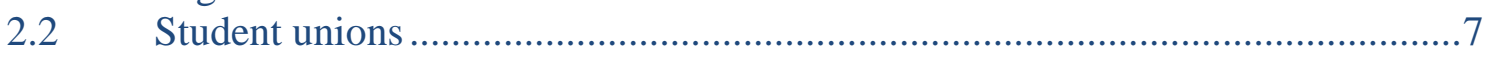

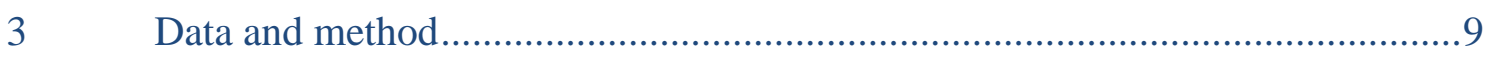

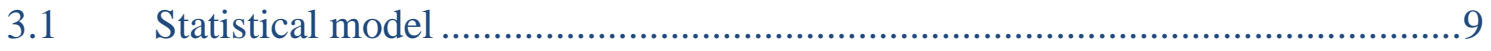

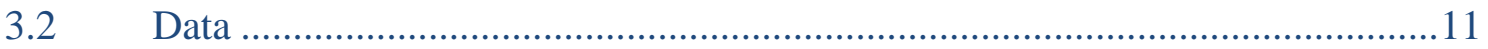

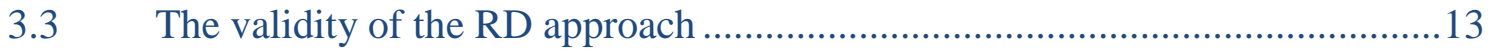

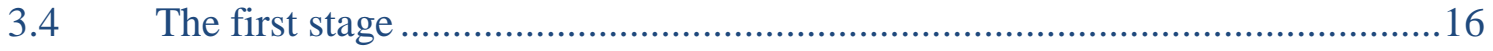

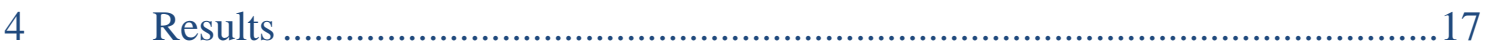

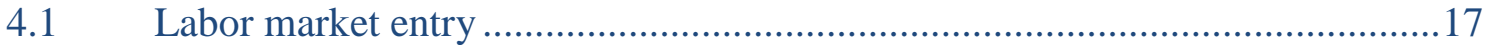

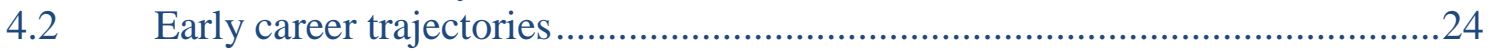

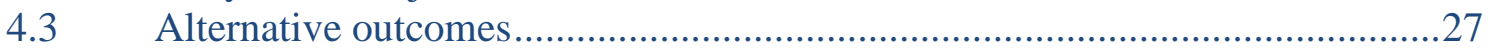

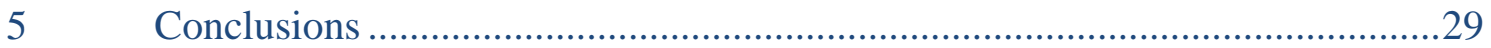

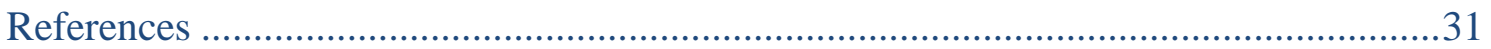

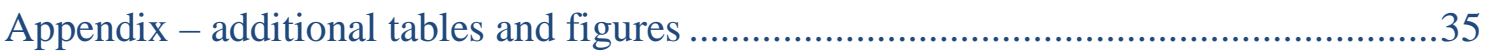




\section{Introduction}

It is popularly perceived that young individuals can improve their labor market prospects by holding a leadership position before entering the labor market. Examples of such activities include editing a school newspaper, coaching children in sports, or serving on the board of a youth organization. Previous studies lend some support to this idea; most notably, Kuhn and Weinberger (2005) show, without making strong causal claims, that high school team captains and club presidents on average have higher future earnings and are more likely to become managers in the future than other high school students. ${ }^{1}$ In this paper, we contribute to the literature by presenting what we believe to be the first study of the causal effect of leadership activities during school years on later labor market outcomes.

The paper makes use of unique data on student union (SU) elections at three major universities in Sweden. We use a regression discontinuity (RD) approach (with a discrete running variable) to isolate differences between closely ranked winners and losers in elections to these SU councils. In contrast to those who just missed being elected to the SU councils, students who acquired a position got high-profile and wellrecognized leadership experiences. ${ }^{2}$ Our outcomes are measured by matching SU election data to population-wide register data on labor market outcomes over time.

Our research strategy has several benefits: The use of register data allows us to move beyond snapshots and assess the dynamic impact of leadership experiences over time. Moreover, we are able to use various measures (based on employment indicators and earnings measures) to characterize the impact on the career trajectories of the students. Finally, and most importantly, the election discontinuities allow us to handle selfselection problems and isolate the causal component of the association between leadership activities and labor market outcomes.

\footnotetext{
${ }^{1}$ A related analysis, of young men's leadership experiences within the military, finds similar positive labor market outcomes that are mainly propagated through increased participation in further education (Grönqvist and Lindqvist 2016). Lozano (2008) and Rouse (2012) also show that leadership activities during high school are positively related to future educational attainment.

${ }^{2}$ Note that a simple Google search indicates numerous university websites, all over the world, where it is claimed that becoming a student representative provides the student with experiences and skills that will enhance the CV. Our own small-scale survey of student representatives in Sweden confirms that the elected students share this perception (see section 2.2 below). In addition, previous research suggests that students who participate in extracurricular activities do so partly in order to improve their labor market prospects (see e.g. Roulin and Bangerter 2013).
} 
Leadership experiences during school years may be important for subsequent labor market outcomes for a number of reasons: ${ }^{3}$ Experiences acquired as a student representative may endow the individual with useful human capital such as leadership skills (Becker 1964). The experience may also serve as a signal of pre-existing (noncognitive) skills or traits to future potential employers. Previous research within the “employer learning” literature (building on Spence’s signaling theory) has, for example, highlighted the role of uncertainty about worker skills at the time of labor market entry (e.g. Altonji and Pierret 2001; Lange 2007; see also Spence 1973). ${ }^{4}$ This uncertainty could be reduced if students have documented experiences of leadership activities during their college years. Finally, being a student representative may provide useful social ties to high-ability students or university officials; prior research has shown that social networks play an important role in the school-to-work transition phase (e.g. Shue 2013; Kramarz and Skans 2014). It should also be noted that these three potential benefits-increased human capital, signaling, and networks-could potentially be counteracted by the crowding out of other useful activities (e.g. studying). A close parallel in terms of possible advantages and disadvantages exists in the literature on working while enrolled in high school or at college. ${ }^{5}$

A study of leadership experiences prior to labor market entry is clearly related to the strand of research focusing on extracurricular activities (ECA). This literature has mainly been developed within other disciplines than economics (e.g. sociology, psychology, and education). ${ }^{6}$ Within economics, the study of ECA has primarily focused on the impact on educational attainment (e.g. Barron et al. 2000; Eide and Ronan 2001; Lipscomb 2007; Lozano 2008; Rees and Sabia 2010; Rouse 2012). A few studies also cover labor market outcomes: Henderson et al. (2006) use nonparametric

\footnotetext{
${ }^{3}$ We will not be able to assess the relative importance of these potential mechanisms.

${ }^{4}$ An important finding in this literature is that the value of signals should deteriorate as the market acquires information that is accumulated through labor market experience. Most of the literature has focused on how the market learns about cognitive skills, but analyses also show similar effects for non-cognitive skills (Hensvik and Skans 2013). Note also that Arcidiacono and colleagues find that higher education reduces the role of employer learning though market experience (Arcidiacono et al. 2010), but this conclusion has been contested (Light and McGee 2012).

${ }^{5}$ The literature includes findings of negative effects on educational achievement (e.g. Stinebrickner and Stinebrickner 2003; Häkkinen 2006) and indications of positive labor market effects, at least in the short run (e.g. Light 2001; Hotz et al. 2002; Häkkinen 2006; Geel and Backes-Gellner 2012).

${ }^{6}$ The analyses have examined a large number of activities (e.g. sports, music, performing arts, student government, and voluntary work) and their relationship to a host of different outcomes: academic achievement, labor market entry, sexual activity, drug use and delinquency, etc. Most of this work has, however, relied on survey-based approaches in a high school setting. A general shortcoming has also been the inability to demonstrate causal evidence for the identified relationships (for a literature review, see Farb and Matjasko 2012).
} 
regression techniques to assess the impact of being a college athlete on subsequent labor market success, finding a positive wage premium. A particularly compelling analysis is provided by Stevenson (2010), who examines the role of sports in spurring a successful job career. She uses the "Title IX" reform in the US (which required high schools to level out gender differences in athletic participation) as a natural experiment to handle self-selection issues. The results show that the ensuing rise in female sports participation significantly increased female labor force participation.

Whereas previous research mostly examines participation in ECAs as such, we focus on the impact of having a leadership position within these activities. In the paper, we use data from a companion (political science) paper of ours (Lundin et al. 2015) where we showed that participation in SU councils increases the probability of running for office within regular politics later in life. For that paper, we collected data on SU candidates and their election outcomes from three major universities (Lund, Stockholm, and Uppsala) between the years 1982 and 2005. ${ }^{7}$ These data are, for the current paper, matched to information from national registers on employment and annual earnings between 1985 and 2010.

The council elections follow a closed-ballot-list election system where groups of students ("student parties”) provide lists of pre-ranked candidates before the elections. The number of students elected as representatives from each list depends on the votes given to each list (all students are eligible to vote). Thus, candidates are admitted in accordance with their rank within each list, and closely ranked winners and losers will be separated by an election threshold. We use these within-list election discontinuities to identify the causal impacts of interest. ${ }^{8}$ Importantly, the lists are compiled with very little knowledge regarding the competition from other parties, and without any election polls, suggesting that students will be unable to sort themselves relative to the discontinuity. Furthermore, we show that the pre-election uncertainty regarding the number of seats allocated to each list is enormous: only 13 percent of the lists receive the same number of seats as in the election the year before. In line with the presumption that students are unable to sort themselves exactly around the thresholds, we find no systematic differences between closely ranked winners and losers in terms of important

\footnotetext{
${ }^{7}$ As these data are drawn from the student unions' own archives, which sometimes were incomplete (in particular concerning the identities of candidates who were not elected), data do not cover all years within each university.

${ }^{8}$ We do not have data on the vote shares of the different parties.
} 
observed and predetermined characteristics such as in-school employment and duration of studies. ${ }^{9}$

Our results show, first, that students who become student representatives in the councils have a markedly increased (20 percentage points) probability of being employed in the year after the election term. The effect is robust to a wide set of possible specifications of the RD model. However, the effect on the probability of being employed is short-lived as other students catch up within two years. We find no impact on the probability of being employed at workplaces, organizations, or industries where previous representatives are employed, suggesting that the benefits are valid across large segments of the labor market.

Second, we find that elected student representatives are significantly more likely to hold a well-paid job (defined as a job with a pay exceeding the median earnings among 30-year-old university graduates) within three years after the SU election than those who marginally failed to be elected. However, similar to the employment responses discussed above, the impact on the probability of holding a well-paid job, although large in the short-run, vanishes over time. As a consequence, we find positive effects on annual earnings for the first few years following the election, but not thereafter.

Overall, our results thus suggest that becoming a student representative causally increases the probability of a rapid transition into the labor market without providing long-term benefits. Although far from a sharp test, the fact that the benefits are transitory (of a duration similar to the learning curve estimated by Lange [2007]) together with the observation that the effects appear not to be confined to specific segments of the labor market (as they should be, if networks were the main driving force) indicates that the key benefit of holding a leadership position may be that it provides a credible signal of important pre-existing non-cognitive skills.

The rest of the paper is structured as follows: Section 2 describes the institutional setting, explaining the role of student unions in Sweden and how students are elected into the councils. Section 3 explains the data and the method and also provides standard RD falsification tests. Section 4 presents the results regarding labor market entry and

\footnotetext{
${ }^{9}$ Our empirical approach resembles recent studies on how participation in "regular politics" affects employment and earnings. Lundqvist (2013) uses Swedish data, finding no effects on subsequent earnings, and Kotakorpi et al. (2013) use Finnish data, finding a short-run positive effect on earnings. The focus of these studies is, however, very different from ours, since they document the relationship between participation in national or sub-national parliamentary elections and labor market performance for adults, often approaching the end of their careers.
} 
career trajectories as well as results related to alternative outcomes such as academic achievement. Section 5 concludes the paper.

\section{Institutional setting}

\subsection{Higher education in Sweden}

In Sweden, public universities and university colleges provide tuition-free higher education. Students are admitted to programs or courses based on grade point averages from high school (GPA) and scholastic aptitude test scores (corresponding to SAT). At the undergraduate level, students can participate in programs, which are usually between three and five years long, or combine single-subject courses into degrees. As a result, students (including those initially admitted to programs) tend to adjust the duration of studies, for example, in response to the results of job-search activities. Therefore, the time it takes to complete a degree varies considerably between students. Almost all students support themselves through generous government grants (loans and allowances) that are available for up to six years for all students irrespective of parental income. As shown below, a large proportion of students add to their income by working while enrolled.

\subsection{Student unions}

Until July 1, 2010, it was mandatory for all students at universities and university colleges in Sweden to be a member of a student union (studentkår). Accordingly, these organizations tend to represent a sizeable student population. While student unions exist in many countries, their features differ somewhat across countries (see e.g. Klemenčič 2012). In some countries, they mostly organize things like cultural and sports activities. In others, such as Sweden and the UK, student unions are more similar to interest organizations; that is, they act as "labor unions." This means that they (try to) influence decisions made by, for example, universities, municipalities, and the national government. Swedish student unions represent the students in every decision-making body within universities, having up to one-third of the seats in these bodies. The unions also provide their members with various kinds of services, such as judicial counseling, housing, and health counseling. Thus, they have some formal power and a fairly important position within the Swedish system of higher education. Notably, since all college educated Swedes were (mandated to be) SU members at some point, these 
organizations and their councils are well known to potential future employers. It is also common knowledge that several prominent Swedish politicians (e.g. former Prime Minister Fredrik Reinfeldt), publicists, and other successful former students were active in the SU councils in their student days.

In our analysis, we focus on three of the largest student unions in Sweden: Uppsala Student Union (Uppsala studentkår), Stockholm University Student Union (Stockholm universitets studentkår), and Lund Student Union (Lunds studentkår). All three organizations have more than 15,000 members. ${ }^{10}$ In each student union there is a "legislative" council and an executive body. Council members are elected by their fellow students on a yearly basis. The electorate votes on "student parties" that present closed lists with a pre-set ranking of council candidates. Ballots are sent to student union members shortly before the elections, and no registration is needed to be able to vote. Some of the parties are ideologically based, whereas others are based on motives such as representing a certain faculty or educational program. Council seats are proportionally allocated to the lists and then distributed according to the (predetermined) candidate ranking within each candidate list. In some of the elections, it was also possible to (try to) alter the predetermined ranking by adding a vote for an individual candidate within the preferred list. ${ }^{11}$ This electoral system mirrors the Swedish public election system.

Within the councils, elected student representatives engage in activities such as debates and negotiations with other parties, and they make budget decisions and decisions about policy proposals as well as determine the allocation of funds to specific student-run projects. Council meetings are held about once a month, but in between meetings, representatives generally spend a considerable amount of time (see below) initiating policy proposals, writing policy documents, and lobbying towards various organizations and authorities on the behalf of student interests.

In the present paper, we are interested in the labor market effects of participating in the SU councils, that is, of taking part in the processes of leading a quite large and

\footnotetext{
${ }^{10}$ In 2010, Uppsala Student Union had about 33,000 members (the largest in Sweden) and Stockholm University Student Union had approximately 20,000 members. In 1990, Lund Student Union had approximately 15,000 members. However, during the second half of the 1990s, Lund Student Union was split up into a large number of faculty-based student unions. Thus, it no longer exists.

${ }^{11}$ A lower-ranked candidate (receiving more individual votes than a higher-ranked candidate) was only moved up in the ranking if his or her share of individual votes exceeded a predetermined threshold. As we show below, the initial rank is, however, a very good predictor of the final outcome.
} 
significant organization during the college years. The experience individuals gain as student representatives might very well be valued on the labor market. A survey ${ }^{12}$ that we carried out among candidates in the SU elections at Uppsala University in 2011 and 2012 indicates that many of the council candidates believe that experiences from SU politics (if they were to be elected) would be important for their future professional careers. For instance, about one third of the candidates noted that professional career motives were a "fairly" or "very" important reason to run in SU elections, and almost two thirds reported that they believed that becoming a council member improves skills and networks that are important on the labor market. Elected council members (surveyed towards the end of their term, $\mathrm{N}=27$ ) emphasized skills they had learned within the council: around 70 percent stated that their labor market skills had increased to a "fairly" or "very" large extent as a consequence of being involved in the activities within the SU council. The survey also indicates that council members devote a lot of time to SU politics: on average 12 hours a week.

\section{Data and method ${ }^{13}$}

\subsection{Statistical model}

We derive the causal effects of becoming a student representative by using the logic of a regression discontinuity (RD) design (Thistlethwaite and Campbell 1960) with a discrete running variable. The basic idea is to compare labor market outcomes for closely ranked winners and losers from the same SU council list. As the election result allocates a certain number of seats to each list, the key threshold is given by the position on each ballot list that coincides with the number of seats allocated to that list. These list-specific thresholds allow some candidates to enter the councils whereas other closely placed candidates on the same ballot lists just miss getting into the councils.

Thresholds have a strong, but not deterministic, relationship to the allocation of SU council seats. There are two reasons for this discrepancy: First, some of our elections permit preferential votes alongside the votes on the lists. In these elections, students who received enough individual votes were treated as first-ranked (we only have very

\footnotetext{
12 The survey was carried out as a web survey. In total, 141 students participated in the survey, which implies a response rate of about 67 percent. Background characteristics of survey participants resemble those of the total population. Thus, non-responses are not likely to bias the results to any important extent.

${ }^{13}$ The exposition (and content) here draws heavily on our previous paper, which focuses on public election candidacies; see Lundin et al. (2015).
} 
imperfect information on the number of votes on each individual). Second, candidates can forfeit their seat. In this case, the first-ranked of the remaining students is elected instead. Obviously, the frequency of individual votes and the probability of forfeiting may be correlated with important unobserved characteristics. For these reasons, we use the relationship between initial ranking and threshold as an instrumental variable for actually acquiring a seat; that is, we make use of the "fuzzy RD design."

Formally, we run the following two-stage regression:

$$
\begin{gathered}
\text { Elected }_{i, l}=\alpha_{l}^{1}+\text { SAbove }_{i}+\varphi^{1}\left(\text { Rank }_{i, l}-T_{l}\right)+\mu^{1}\left(\text { Rank }_{i, l}-T_{l}\right) \text { Above }_{i}+X_{1} \beta^{1}+\varepsilon_{l}^{1} \\
\text { Outcome }_{i, l}=\alpha_{l}^{2}+\gamma \text { Elected }_{i}+\varphi^{2}\left(\text { Rank }_{i, l}-T_{l}\right)+\mu^{2}\left(\text { Rank }_{i, l}-T_{l}\right) \text { Above }_{i}+X_{1} \beta^{2}+\varepsilon_{l}^{2}
\end{gathered}
$$

We let Outcome denote our various variables measuring labor market outcomes for individual $i$, Rank is the list-ranking in the SU council election, $T$ is the list-specific threshold (defined by the number of seats allocated to the list), Above is a dummy variable taking the value one if the individual is placed above the threshold, Elected is a dummy variable for being elected into the SU council, $\alpha$ is a fixed effect for each list (denoted by $l$ ) and, finally, there is an error term for each stage. The parameter of interest is $\gamma$, which captures the effect of being elected on the outcome measures. We also add a set of individual-level covariates (age, sex, immigration status, duration of studies, and previous work experience), denoted by $X$, to increase the precision of the estimates.

Note that our running variable will be the list rank, which is discrete. Hence, our RD model is explicitly estimated by comparing linear predictions from the two sides towards the threshold, which in practice closely mimics standard procedures in applications with continuous running variables (see e.g. Lee and Lemieux 2010). However, some standard tests (including those of optimal bandwidth) do not apply in this case. ${ }^{14}$

Although most of our outcomes are binary, the models are estimated as linear probability models following standard procedures in the RD literature. Throughout, we

\footnotetext{
${ }^{14}$ Lee and Card argue for clustering on specific values of the running variables due to the fact that the functional form may be misspecified (hence generating error correlations within such clusters) (Lee and Card 2008). We treat each list-specific rank as an independent observation. As in most applications, clustering on each rank across lists gives smaller estimated standard errors, presumably since the number of clusters becomes too small.
} 
rely on standard errors that are robust to heteroscedasticity and clustered to account for repeated observations at the individual level (referring to about one third of the individuals). We return to the issue of repeated observations in section 4.1.1.

\subsection{Data}

We have gathered archive data from the three analyzed Swedish student unions (i.e. Uppsala, Stockholm, and Lund), including information on SU council elections between 1982 and 2005. We recorded party list names, candidate rankings, and social security numbers (personnummer) of individual candidates, as well as election results and indicators for taking up the seat in the council and for representation on the SU board. We use information for the somewhat scattered set of years (see the Appendix for details, Table A 1) for which we could find information. Raw data cover 30 different SU elections (5,154 candidates). Using the social security numbers, Statistics Sweden has matched our SU data onto national registers containing basic demographics (sex, age, and immigration status), some basic educational information, and labor market outcomes such as employment and earnings during 1985-2010. Unfortunately, we do not have data on the vote shares of the different parties.

We exclude the few SU election lists where none or all of the candidates were elected, since we only have candidates on one side of the threshold within those lists. Candidates whose rank is higher than the total number of seats available in the SU council are also excluded throughout, since they have a zero probability of becoming elected. Last, to focus the analysis on a sample of reasonably inexperienced students, we remove candidates older than 40 (removing only 60 observations, without affecting the results). The final data set has a patchy coverage, but it is fairly evenly distributed across universities and years (see Table A 1 in the appendix).

Table 1 reports descriptive statistics of SU council candidates above and below the election thresholds. The first two columns include all candidates, whereas the last two columns focus on our main sample consisting of the five candidates closest to the thresholds. Candidates are considered to be above the threshold if their list rank is at least as high as the number of seats allocated to their list. 
Table 1 Descriptive statistics

\begin{tabular}{|c|c|c|c|c|}
\hline & \multicolumn{2}{|c|}{ All (irrespective of ranking) } & \multicolumn{2}{|c|}{ Closest 5 (main sample) } \\
\hline & $\begin{array}{l}\text { Above } \\
\text { threshold }\end{array}$ & $\begin{array}{l}\text { Below } \\
\text { threshold }\end{array}$ & $\begin{array}{l}\text { Above } \\
\text { threshold }\end{array}$ & $\begin{array}{l}\text { Below } \\
\text { threshold }\end{array}$ \\
\hline \multicolumn{5}{|l|}{ Individual data } \\
\hline Candidate age (years) & 24.4 & 24.7 & 24.3 & 24.4 \\
\hline Women (proportion) & 0.410 & 0.383 & 0.393 & 0.400 \\
\hline Immigrants (proportion) & 0.075 & 0.067 & 0.076 & 0.063 \\
\hline Duration of studies (years) & 3.910 & 3.961 & 3.773 & 3.632 \\
\hline Employed the year before (proportion) & 0.423 & 0.447 & 0.408 & 0.431 \\
\hline SU experience (proportion) & 0.388 & 0.165 & 0.340 & 0.198 \\
\hline $\begin{array}{l}\text { Elected to SU council } \\
\text { (proportion, main independent variable) }\end{array}$ & 0.891 & 0.035 & 0.881 & 0.084 \\
\hline Number of observations & 1,257 & 3,897 & 919 & 1,251 \\
\hline Number of unique individuals & 843 & 2,731 & 687 & 1,031 \\
\hline \multicolumn{5}{|l|}{ Lists (parties per year and university) } \\
\hline Number of included candidates per list & 4.3 & 13.4 & 3.2 & 4.3 \\
\hline Total number of lists & 290 & 290 & 289 & 289 \\
\hline \multicolumn{5}{|l|}{ Election cohorts (year and university) } \\
\hline Average number of lists per election & 9.7 & 9.7 & 9.6 & 9.6 \\
\hline Number of elections & 30 & 30 & 30 & 30 \\
\hline
\end{tabular}

Note: The data on the left-hand side exclude SU council candidates with a ranking above the number of available seats in the SU council. The two last columns focus on the five students on each side who are closest to each threshold.

Table 1 shows that there are 30 election cohorts (year×university). On average, there are approximately 10 lists participating in each election. Candidates above and below the thresholds are similar in terms of mean age (24 years), the proportion of immigrants (0.07), and the proportion of women (0.40). The main used sample does not diverge from the full sample to any noticeable extent. For reasons discussed above, candidates above the threshold do not always acquire their seat in the council. Yet, the threshold has a huge impact on who enters the council: the proportion increases from 0.08 if falling below the threshold to 0.88 if being placed above it.

Two main outcome variables are examined in the paper: employment and whether the individual has as well-paid job. Employment is measured each year in November using an indicator calculated by Statistics Sweden (producing employment rates that are roughly similar to those of the labor force survey). We use data from one year $(t-1)$ before participating in SU council elections to five years $(t+5)$ after the election. If the individual earned at least as much as the median 30-year-old with a college education, he or she is considered to have a well-paid job. We also present results for the probability of earning above the $75^{\text {th }}$ percentile. 
Figure 1 Fraction of SU council candidates in employment and having a well-paid job relative to the year of the SU council election

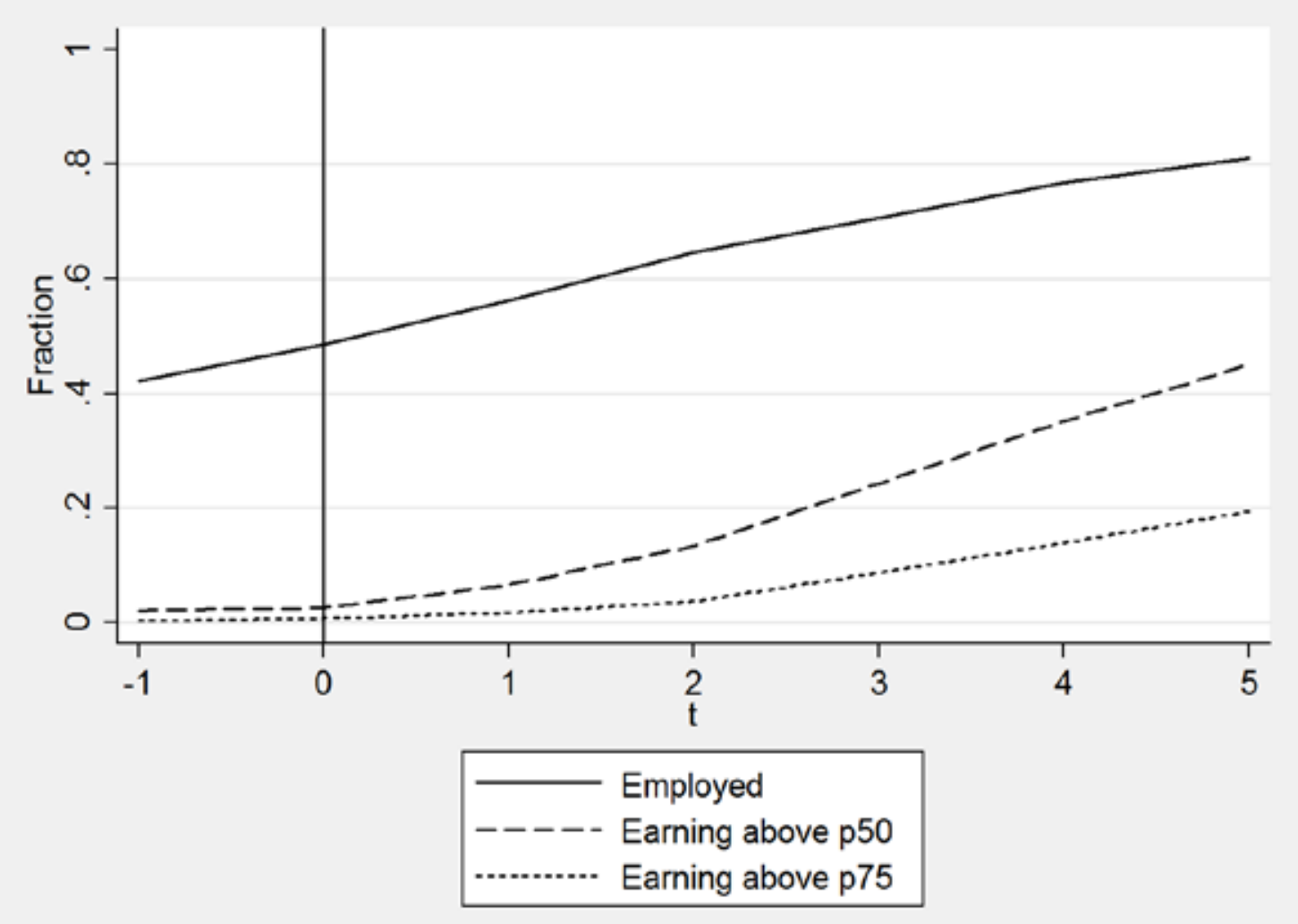

Notes: The employment indicator captures employment in November according to Statistics Sweden’s algorithm. The earnings thresholds (p50 and p75) refer to percentiles within the distribution of annual earnings among all 30-yearolds with a university degree (masters or bachelor). $X$-axis: years relative to year of election $(t=0)$.

Figure 1 shows that almost 60 percent were employed one year after participating in the SU council election. Very few, about 5 percent, earned more than the median 30-yearold with a college education at that initial stage in their career. This is not surprising, given that the students are 24 years old on average when they run in the SU elections. Using a higher earnings threshold (the 75 percentile) instead, we see that very few reached this level until at least three years after the election. Equally unsurprising, the candidates have very positive career trajectories: five years after the SU elections, more than 80 percent had a job, while around 45 percent had reached the median, and 20 percent had reached the 75 percentile of 30-year-old college graduates.

\subsection{The validity of the RD approach}

Our analysis relies on the key assumption that there are no systematic differences in abilities or skills between candidates across the threshold, apart from those that are captured by the rank variables. This assumption will be valid if the parties are unaware 
of how many seats they will acquire when they compile the lists, since candidates can only self-sort exactly around the threshold if it is known beforehand.

Importantly, there are three very strong reasons for why the election thresholds in our particular setting are very difficult to predict: First, party lists are constructed, and votes are cast, with very little information. When lists are compiled, potential candidates are not able to foresee who they are competing against in terms of the number and nature of competing parties. Students come and go, which generates large variation in the sets of candidates from year to year even within more stable parties, and there are frequent entries and exits of entire parties. Thus, it is not possible for the parties to exactly monitor changes in their competition, nor changes in voting students' preferences, and it is an even more demanding task to predict the effect on such changes on their expected number of seats. No opinion polls are held, which also makes it very hard for the candidates to predict the voting patterns.

Second, the number of seats per party is very volatile between years. Figure 2 displays the distribution of new seats in the SU elections. Only a low 13 percent of the lists received the same number of seats in two consecutive elections. This means that only one in eight seats in the councils were allocated to a list that remained at a stable representation since the last election. This reflects both a frequent entry and exit of parties between elections, and very volatile voting patterns. 
Figure 2 Distribution of new seats among lists receiving seats in SU council elections

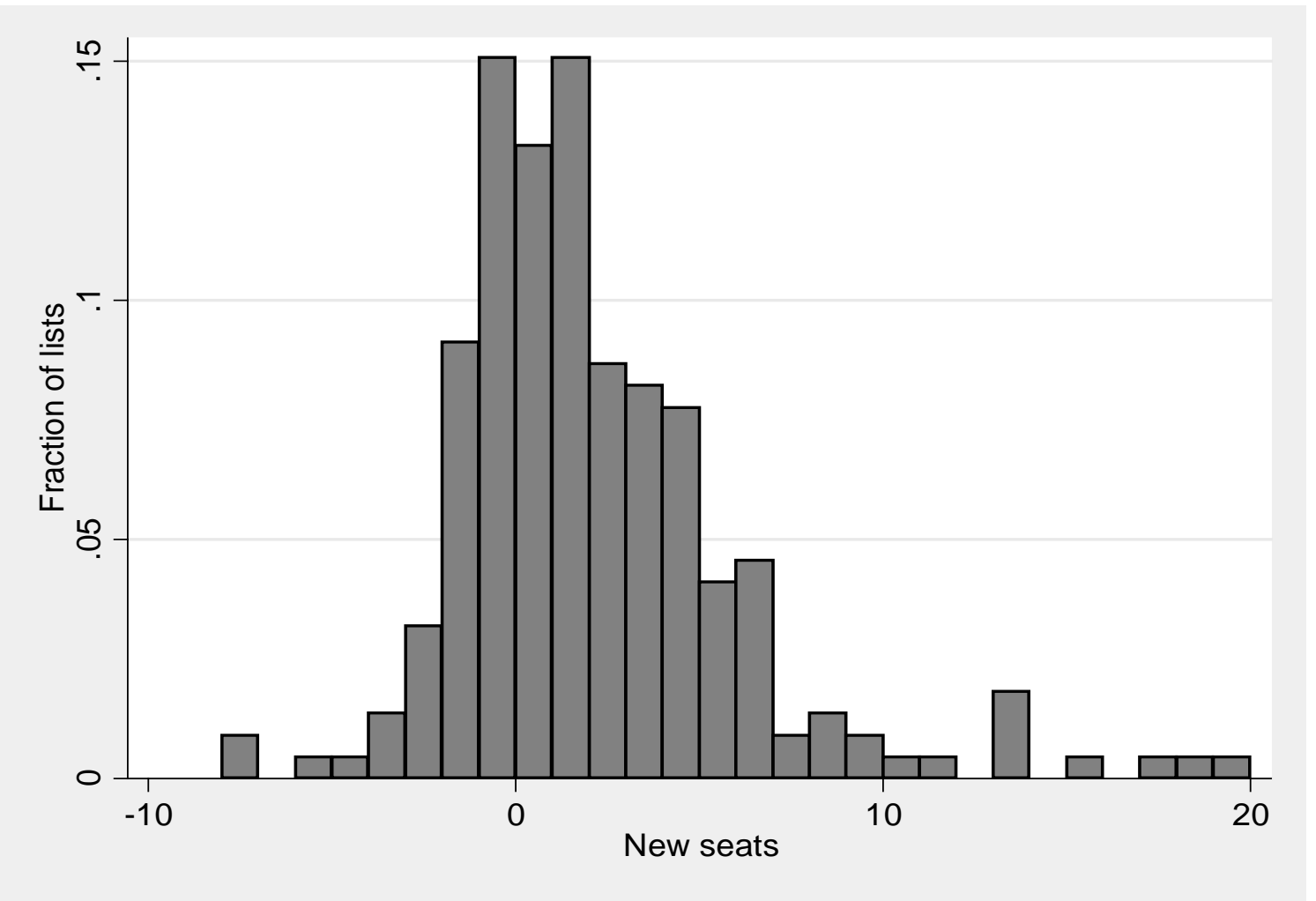

Note: Figure is reproduced from (Lundin et al. 2015).

Last, we have conducted a survey among recent SU council candidates at one Swedish university (see section 2.2). This survey demonstrates that SU council candidates themselves are unable to predict whether they will be elected or not, prior to SU elections. Once we removed candidates that were very far from the thresholds, the respondents were wrong almost as often as they were right when predicting the outcome (and many declared that they could not make a prediction). ${ }^{15}$

As is standard in the RD literature, we have tested the prediction that closely ranked winners and losers, on average, have identical observed characteristics after controlling for the rank-distance to the threshold. If our assumptions are valid, this should be the case. This is examined by estimating equation (1) using observed predetermined characteristics as outcome variables.

\footnotetext{
${ }^{15}$ This analysis is presented in the online appendix to Lundin et al. (2015).
} 
Table 2 Validity test: results from estimations of equation (1) using predetermined characteristics as outcome variables

\begin{tabular}{lcccccc}
\hline & Female & Immigrant & Age & $\begin{array}{c}\text { Years since } \\
\text { start of } \\
\text { studies }\end{array}$ & $\begin{array}{c}\text { Employed } \\
\text { the year } \\
\text { before }\end{array}$ & $\begin{array}{c}\text { SU } \\
\text { experienced }\end{array}$ \\
\hline Estimate & -0.022 & 0.012 & -0.009 & 0.254 & 0.008 & -0.013 \\
(s.e.) & $(0.064)$ & $(0.034)$ & $(0.394)$ & $(0.318)$ & $(0.065)$ & $(0.057)$ \\
\hline Mean dep. var. & 0.397 & 0.0687 & 24.36 & 3.692 & 0.421 & 0.260 \\
N & 2,170 & 2,170 & 2,170 & 2,167 & 1,847 & 1,924 \\
\hline
\end{tabular}

Notes: Estimates based on equation (1) using the threshold as an instrument for being elected into the SU council. All models include list fixed effects. The model does not include any additional covariates and corresponds to the first column in Table 3 below. The sample includes the first five candidates on each side of the threshold. The last three columns have slightly fewer observations due to missing values on the outcome variables (from truncation of the sample window). Standard errors are clustered at the individual level and robust to heteroscedasticity. $*=$ sign. at $<$ 0.10 . $* *=$ sign. at $<0.05$. $* * *=$ sign. at $<0.01$.

Table 2 shows that neither sex, immigration status, age, duration of studies, previous work experience, nor experience from previous years' SU councils changes significantly around the threshold. ${ }^{16}$ All point estimates are also very small compared to the means of the variables. An F-test shows that the variables in a regression on the instrument are jointly insignificant. Last, including all the variables in the main analysis has no impact on the results, as we will show below. Note that the standard RD test of the number of observations on the two sides of the threshold holds by construction in our case since the running variable is a rank, but a figure is nevertheless supplied in the appendix (Figure A 1).

\subsection{The first stage}

In our main analysis we use the IV model outlined in section 3.1. As already indicated above, the first stage is very strong. The relationship between rankings and thresholds and the probability of being elected is depicted in Figure 3. It shows that there is a major jump in the election probability exactly at the threshold. The fact that there is a small deviation from the linear predictions of the ranking variable for the closest observations is consistent with the fact that preferential votes on individual candidates can push the last candidate down across the threshold, while forfeited seats are allocated to the last candidate below the threshold.

\footnotetext{
${ }^{16}$ These variables constitute a nearly exhaustive list of the predetermined variables that are available in our data. In our companion paper (Lundin et al. 2015), we also show that the probability of having participated in a public election before being a SU candidate is also balanced at the threshold.
} 
Figure 3 First stage: being elected to a SU council as a function of distance to threshold (ranking)

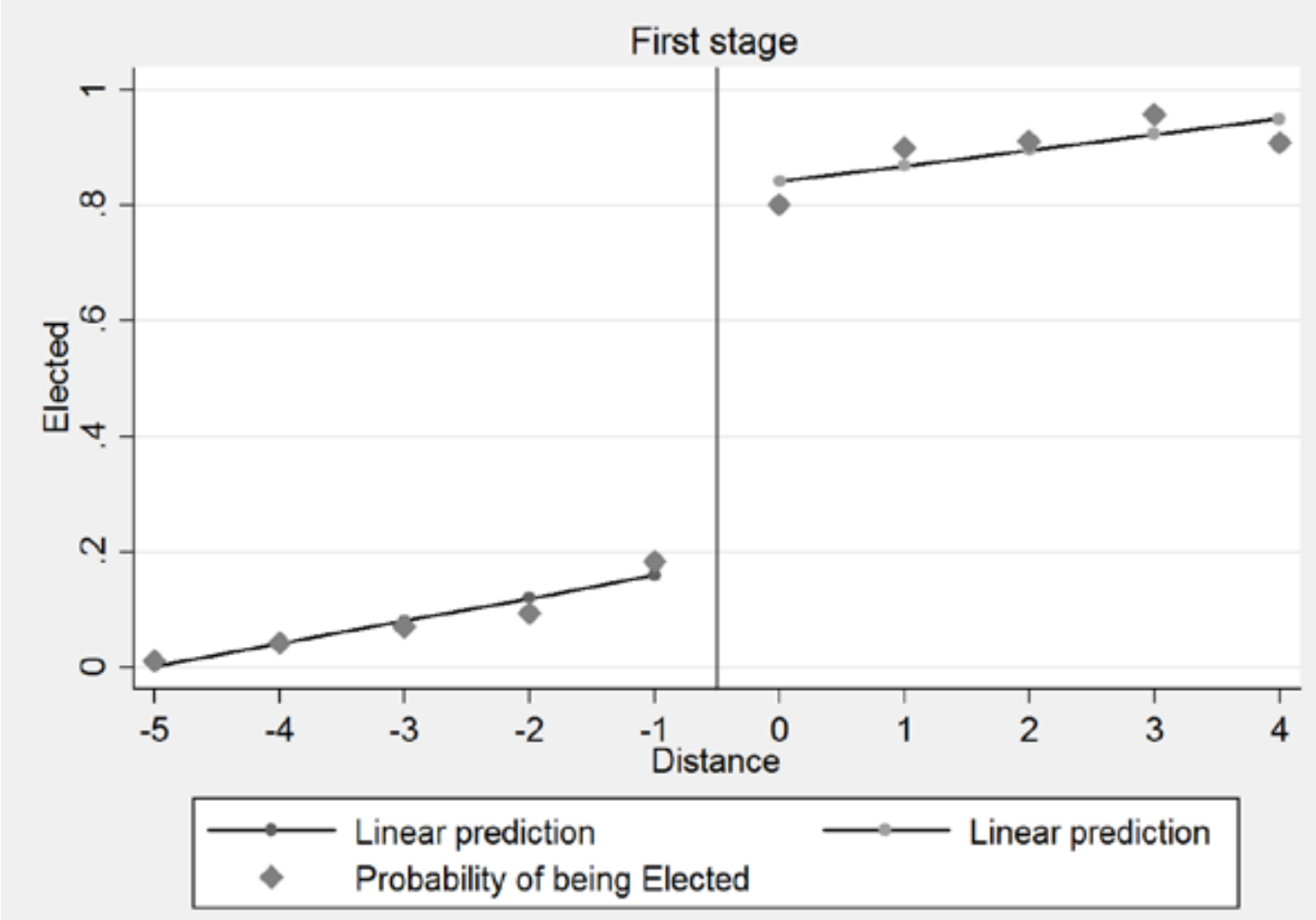

\section{$4 \quad$ Results}

We present the main results in two subsections, beginning with the impact of becoming student representative on labor market entry and then turning to the impact on subsequent early career trajectories.

\subsection{Labor market entry}

We use the model of equation (1) to estimate the impact on the probability of employment; for completeness we show results for years both before and after the SU election. As expected, the results in Figure 4 indicate no effects during the year before the election $(t=-1)$ or during the year of actual participation in the SU council $(t=0)$. More importantly, the figure clearly shows that becoming a student representative in a SU council has a positive impact on employment during the first year after the SU election. Candidates who were marginally elected to a SU council were 20 percentage points more likely to be employed at that time than SU candidates who just missed being elected (starting from a baseline of about 45 percent). As demonstrated above in 
Figure 1, this is a phase of very fast career progression and the effect therefore wears off rapidly as other students catch up. Thus, the effects on employment probabilities are statistically insignificant two to five years after the election. With the exception of year 2, for which the point estimate suggests an impact of around 8 percentage points, the point estimates also remain small after the initial year.

Figure 4 The impact of becoming a student union representative on employment up to five years after SU council elections

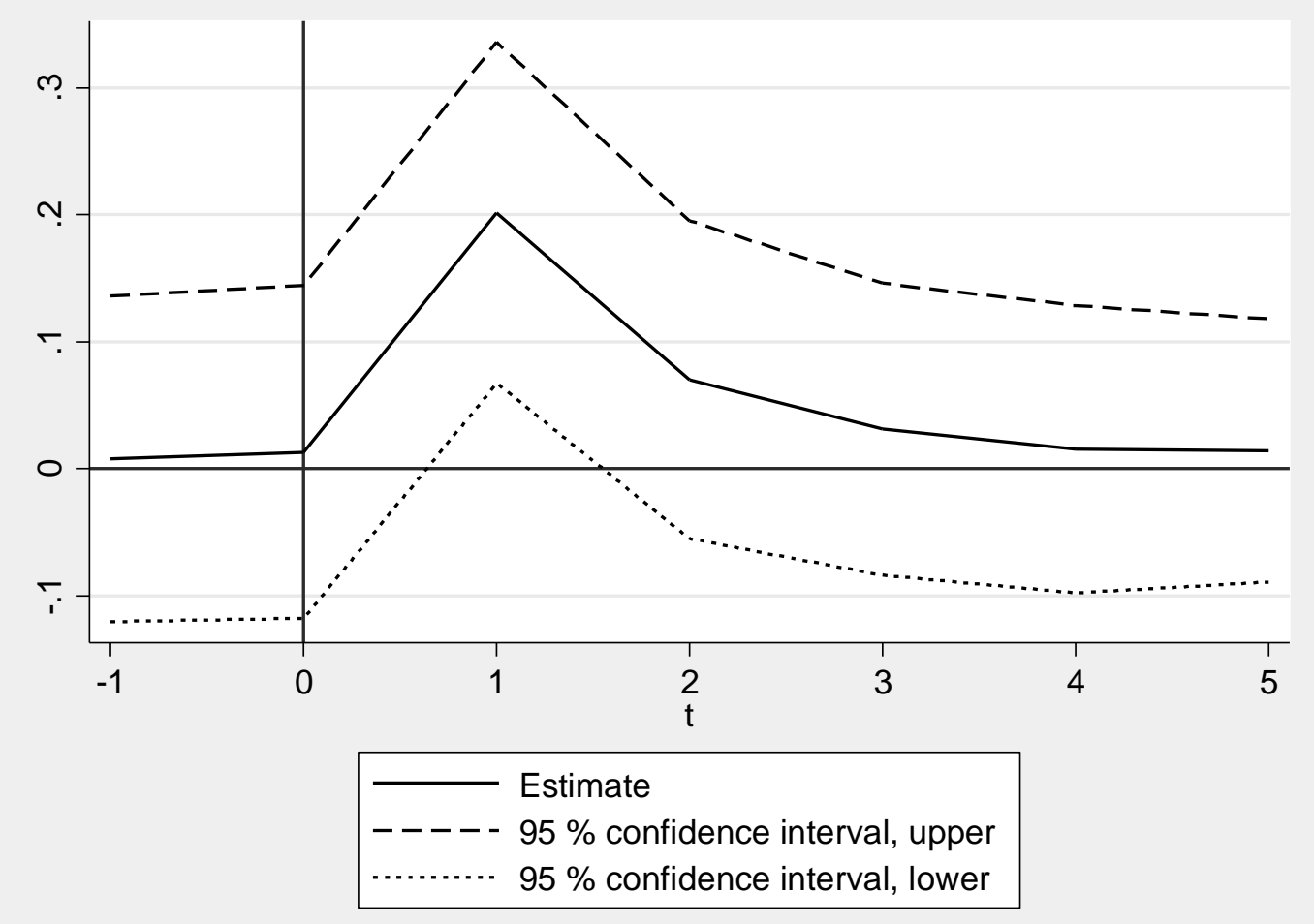

Notes: The figure depicts regression coefficients (and $95 \%$ confidence intervals) from instrumental variables models (see equation 1) from $t-1$ to $t+5$, where $t=0$ is the year when the student participated in the SU council elections. The $Y$-axis indicates estimates of how the probability of being employed changes if the student gets elected. $X$-axis: years relative to year of election $(t=0)$.

In order to assess the robustness of the estimated first-year impact, Table 3 shows detailed results from various models, consistently using employment during the year after the election as the outcome. Column 1 shows the estimates from a simple model which only captures the impact of rankings by a common linear term. Column 2 adds an interaction between the ranking and the threshold. Column 3 presents our preferred model (corresponding to Figure 4 above), which also includes controls for demographics, duration of studies, and pre-election employment. In column 4, we enter the ranking variables with quadratics (separately above and below). In column 5, we revert 
to the model of equation (1), but use a narrower sample window containing only the three closest candidates. Finally, column 6 relies only on the two truly marginal candidates within each list (hence, without controlling for the ranking). ${ }^{17}$

Table 3 The impact on employment one year after the SU election: robustness

\begin{tabular}{|c|c|c|c|c|c|c|}
\hline & 1 & 2 & 3 & 4 & 5 & 6 \\
\hline $\begin{array}{l}\text { Estimate } \\
\text { (s.e.) }\end{array}$ & $\begin{array}{c}0.193^{\star \star \star} \\
(0.063)\end{array}$ & $\begin{array}{l}0.201^{\star \star \star} \\
(0.069)\end{array}$ & $\begin{array}{l}0.200 * \star \star \\
(0.066)\end{array}$ & $\begin{array}{l}0.246^{*} \\
(0.136)\end{array}$ & $\begin{array}{l}0.213^{\star \star} \\
(0.098)\end{array}$ & $\begin{array}{l}0.143^{\star} \\
(0.079)\end{array}$ \\
\hline $\mathrm{N}$ & 2,106 & 2,106 & 2,106 & 2,106 & 1,416 & 522 \\
\hline Sample, closest: & 5 & 5 & 5 & 5 & 3 & 1 \\
\hline Covariates & No & No & Yes & Yes & Yes & Yes \\
\hline Ranking & Yes & Yes & Yes & Yes & Yes & No \\
\hline $\begin{array}{l}\text { Ranking*above } \\
\text { threshold }\end{array}$ & No & Yes & Yes & Yes & Yes & No \\
\hline Quadratic terms & No & No & No & Yes & No & No \\
\hline
\end{tabular}

Notes: Estimates are from instrumental variables models (see equation 1) using the threshold as an instrument for being elected to the SU council. Covariates are the ones presented in Table 2 and indicators for missing values of the last three of these. Standard errors (within parentheses) are clustered for repeated observations at the individual level and robust to heteroscedasticity. ${ }^{*}=$ sign. at $<0.10 .{ }^{*}=$ sign. at $<0.05 . * * *=$ sign. at $<0.01$.

The results are robust to the inclusion or exclusion of covariates, to changes in the functional form of the rank controls (linear, split, quadratic), and to narrowing the sample bandwidth to the closest three candidates, or to focusing on the truly marginal candidates. The most noticeable differences across the columns are that the statistical precision is reduced (to significance at the 10 percent level) when including the quadratic term and that the estimate is somewhat smaller when focusing on the two marginal candidates.

Figure 5 shows the reduced form relationship non-parametrically after removing the list fixed effects, but without accounting for potential differences in other covariates. Clearly, this relationship looks reasonably linear away from the threshold. There appears to be some added noise for students who were elected with a broad margin (i.e., with a distance of 3 and 4), but this is not surprising since there are fewer observations at these points (see the density plot in Figure A 1).

\footnotetext{
${ }^{17}$ Figure A 6 provides results for all bandwidths.
} 
Figure 5 Reduced form relationship between list rankings and first-year employment

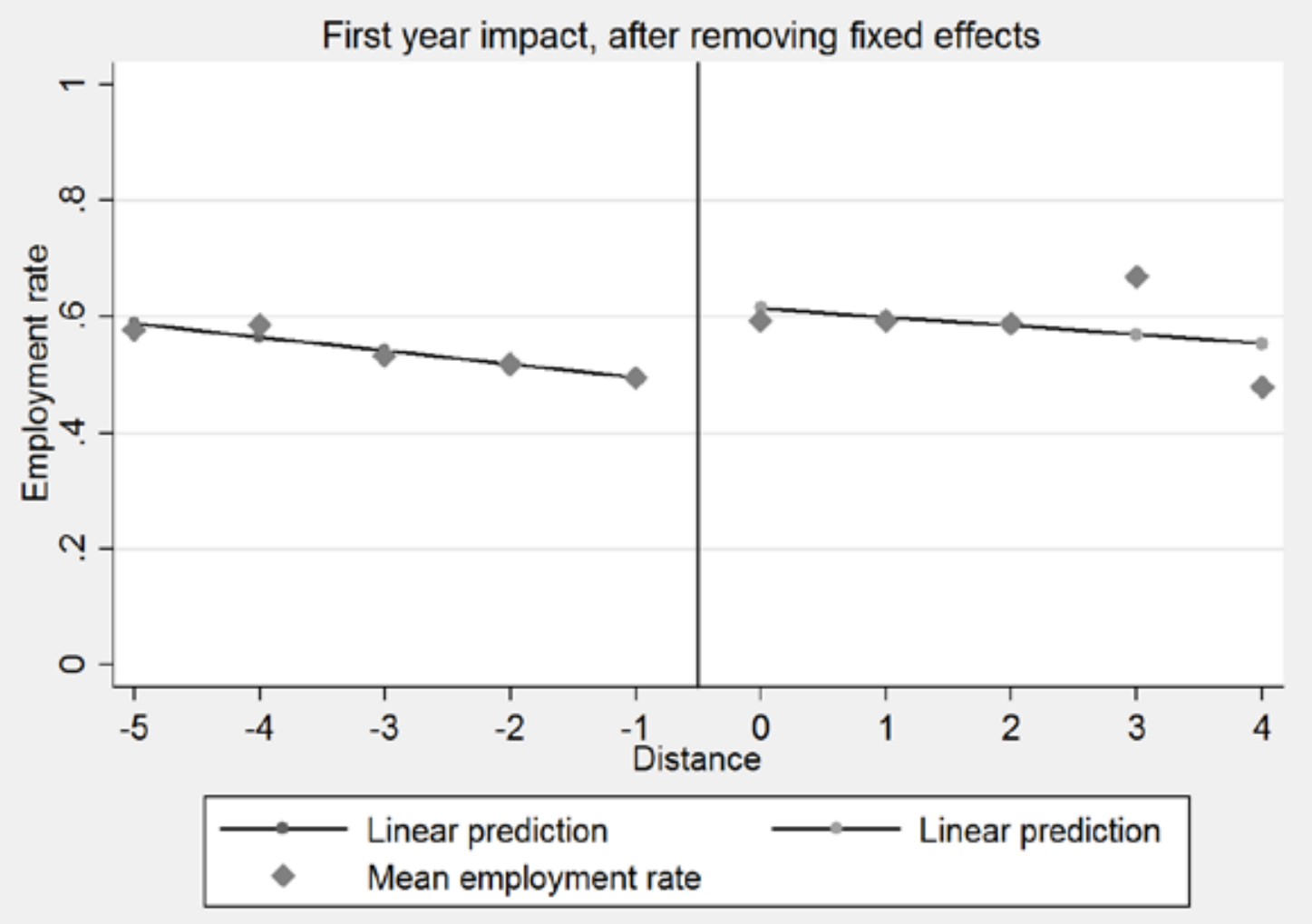

\subsubsection{Repeat candidacies}

The students included in our data sometimes appear multiple times. In the baseline specifications we handle this by clustering the standard errors on the students to ensure that the inference is not biased by repeat candidacies. An implicit assumption behind this strategy is that the effect of being elected once is the same as the effect of being elected a second time. In this case, the model is correctly specified if we are willing to accept that responses through future (endogenous) candidacies are part of the effects we are estimating. However, this implies that the short-run nature of the effects could be explained by repeat candidacies in subsequent elections if the returns to being elected are highly concave (e.g., what matters is if you have been elected, not how many times) so that losers either catch up through subsequent wins or are more willing to run (and win) again later. In order to study these concerns, we have performed a number of additional exercises. 
Table 4 The role of repeat candidacies

\begin{tabular}{|c|c|c|c|c|c|}
\hline & $\begin{array}{c}\text { Outcome: } \\
\text { Employment } \\
(t+1)\end{array}$ & $\begin{array}{l}\text { Outcome: } \\
\text { Future SU } \\
\text { seat }\end{array}$ & $\begin{array}{c}\text { Outcome: } \\
\text { Employment } \\
(t+1)\end{array}$ & $\begin{array}{c}\text { Outcome: } \\
\text { Employment } \\
(t+3)\end{array}$ & $\begin{array}{c}\text { Outcome: } \\
\text { Employment } \\
(t+3)\end{array}$ \\
\hline $\begin{array}{l}\text { Estimate } \\
\text { (s.e.) } \\
\text { Interacted with } \\
\text { past-seat dummy }\end{array}$ & $\begin{array}{c}0.200 * \star \star \\
(0.066)\end{array}$ & $\begin{array}{l}0.116^{\star \star} \\
(0.058)\end{array}$ & $\begin{array}{c}0.193^{\star \star \star} \\
(0.067) \\
-0.070 \\
(0.072)\end{array}$ & $\begin{array}{c}0.024 \\
(0.058)\end{array}$ & $\begin{array}{c}0.029 \\
(0.074)\end{array}$ \\
\hline $\mathrm{N}$ & 2,106 & 2,042 & 1,376 & 2,139 & 1,495 \\
\hline Sample & Baseline & Baseline & $\begin{array}{l}\text { Non-missing } \\
\text { dummy for } \\
\text { past seat }\end{array}$ & Baseline & No future seat \\
\hline Covariates & Yes & Yes & Yes & Yes & Yes \\
\hline Ranking & Yes & Yes & Yes & Yes & Yes \\
\hline $\begin{array}{l}\text { Ranking*above } \\
\text { threshold }\end{array}$ & Yes & Yes & Yes & Yes & Yes \\
\hline
\end{tabular}

Notes: Estimates are from instrumental variables models (see equation 1) using the threshold as an instrument for being elected to the SU council. All models include list fixed effects. The sample consists of the five candidates closest to the threshold. Covariates are the ones presented in Table 2 and indicators for missing values of the last three of these. Note that these "covariates" include a dummy for past seats. Standard errors (within parentheses) are clustered for repeated observations at the individual level and robust to heteroscedasticity. $*=$ sign. at $<0.10$. $* *=$ sign. at $<0.05 . * * *=$ sign. at $<0.01$.

Results are presented in Table 4 (column 1 reproduces the main results from Table 3). First, we study whether winning an election has a causal impact on the frequency of future wins (column 2). ${ }^{18}$ The results imply that the winners are actually somewhat more likely to win again, which implies that the convergence is not driven by losing students catching up in terms of the number of wins. Instead, the results suggest that there is some additional divergence in terms of the total number of wins over time.

Second, we have tried to analyze whether the effects differ between students with and without previous experience from within the council (column 3). To gain precision, we estimate a pooled model where we interact the variable of interest (and the instrument) with the dummy for previous wins. The point-estimate for the interaction is negative, but statistically insignificant.

Finally, we have estimated the time path for the employment effects while excluding all winners of future elections. Although this sample is endogenously selected, we believe it to be an illustrative exercise. The results for the full time profile corresponding to Figure 4 are shown in the appendix (Figure A 7). The figure shows a very similar time profile as in the main analysis, suggesting that the dynamics are not driven by the repeat candidates. In the last two columns (i.e., columns 4 and 5) of Table 4, we zoom

\footnotetext{
${ }^{18}$ We focus on the process of winning later, since we can do this much better than analyzing subsequent candidacies. The reason is that we collected data on winners also in years when data on candidates were missing. We treat cases where the election outcomes are missing for the next year as missing observations.
} 
in on the impact after three years using the baseline sample and the (endogenous) sample of candidates without future wins, respectively. The estimates are very similar and in both cases the initial effects have clearly worn off after three years.

It can also be noted that the overall fraction of losing candidates who become elected to the council in subsequent elections is 18.3 percent, which bounds the repeat candidacy bias to 0.036 percentage points $(0.18 \times 0.200)$ under the extreme assumption that only the first experience as a SU council member matters (and using the estimate of 0.200 from column 1 for the impact). In sum, we believe that the findings do suggest that repeat candidacy is not a major explanation for why losing candidates catch up over time, despite the fact that the effect for repeated leadership experiences may be marginally smaller than the effect of the first experience (as indicated by column 3).

\subsubsection{Effects on different types of students}

A next set of analyses on labor market entry deals with issues of heterogeneity. Table 5 shows the results of analyses using various subsamples. First, we split the sample according to previous employment; that is, into samples of those employed and not employed, respectively, during any of the past three years. Table 5 shows that the results primarily appear to be driven by the subset of students who lack previous work experience: the estimate is significant at the 10 percent level and almost twice as large as for the group of students who have worked before $(0.24$ vs. 0.14$)$. This suggests that experiences as a student representative may be a substitute for work experience, for example, by providing similar types of references or signals of traits or abilities. Taken at face value, the point estimates suggest that in order to reconcile the results with a human capital story one would need to assume that the human capital acquired through leadership experiences adds very little for those with some basic work experience.

The next two columns of Table 5 focus on the elapsed duration of studies. We find that the impact of being a student representative on labor market entry is significant, with similar point estimates, both for those who have a maximum of three years of prior university studies and those who have at least four years of university studies before the election. This is consistent with the notion of a large variation in the duration of studies at Swedish universities and university colleges discussed in section 2.1. The final two columns show that the impact is similar for men and women. 
Table 5 The impact on employment one year after the SU election: heterogeneity

\begin{tabular}{|c|c|c|c|c|c|c|c|}
\hline & \multirow[t]{2}{*}{ Baseline } & Emplo & before & \multicolumn{2}{|c|}{$\begin{array}{c}\text { Years since start of } \\
\text { studies }\end{array}$} & \multicolumn{2}{|c|}{ Sex } \\
\hline & & No & Yes & 3 or less & 4 or more & Male & Female \\
\hline $\begin{array}{l}\text { Estimate } \\
\text { (s.e.) }\end{array}$ & $\begin{array}{l}0.200^{\star \star \star} \\
(0.066)\end{array}$ & $\begin{array}{l}0.238^{*} \\
(0.139)\end{array}$ & $\begin{array}{c}0.137 \\
(0.087)\end{array}$ & $\begin{array}{l}0.181^{*} \\
(0.100)\end{array}$ & $\begin{array}{l}0.201^{*} \\
(0.107)\end{array}$ & $\begin{array}{l}0.204^{\star \star} \\
(0.084)\end{array}$ & $\begin{array}{l}0.254^{\star \star} \\
(0.129)\end{array}$ \\
\hline $\mathrm{N}$ & 2,106 & 676 & 1,163 & 1,110 & 993 & 1,268 & 838 \\
\hline Mean dep.var. & 0.562 & 0.428 & 0.641 & 0.506 & 0.624 & 0.553 & 0.575 \\
\hline Sample, closest: & 5 & 5 & 5 & 5 & 5 & 5 & 5 \\
\hline Covariates & Yes & Yes & Yes & Yes & Yes & Yes & Yes \\
\hline Ranking & Yes & Yes & Yes & Yes & Yes & Yes & Yes \\
\hline $\begin{array}{l}\text { Ranking*above } \\
\text { threshold }\end{array}$ & Yes & Yes & Yes & Yes & Yes & Yes & Yes \\
\hline
\end{tabular}

\subsubsection{Effects on different segments of the labor market}

The next step of the analysis is to examine where student candidates find employment. In particular, we are interested in whether the positive impact on employment is driven by access to certain establishments, organizations, or industries where the skills or networks of student representatives are likely to be particularly relevant. In order to investigate this hypothesis without relying on speculation regarding which segments these may be, we rely on data on the actual working patterns of previous student representatives (again using register data).

The results are displayed in Table 6. In the first column, we use a dummy that takes the value one for students who find employment at an establishment where a previous elected representative is already employed. The dummy takes the value zero if this is not true, regardless of whether the student is employed or not. The second column replicates this analysis using the number of previously elected representatives within the establishment as the outcome (again, taking the value zero also if non-employed). None of these exercises indicate that jobs are found at establishments with a specific need for previous student representatives. Column 3 replicates the analysis of column 2 at the firm or organizational level. An organization can, for example, be a government agency, a municipality, or a university. Again, the estimates are both small and insignificant. Finally, we re-estimate the model at the (2-digit) industry level with similar results, although the point estimates now are much larger since the mean baseline probability of ending up in a particular industry, for obvious reasons, is much larger than ending up at a particular establishment. The final column shows the impact on working with non- 
elected previous candidates and the result gives a similar picture. Overall, we interpret the results as suggesting that the benefits of being a student representative are of a general nature. $^{19}$

Table 6 Impact on the probability of being employed with former representatives

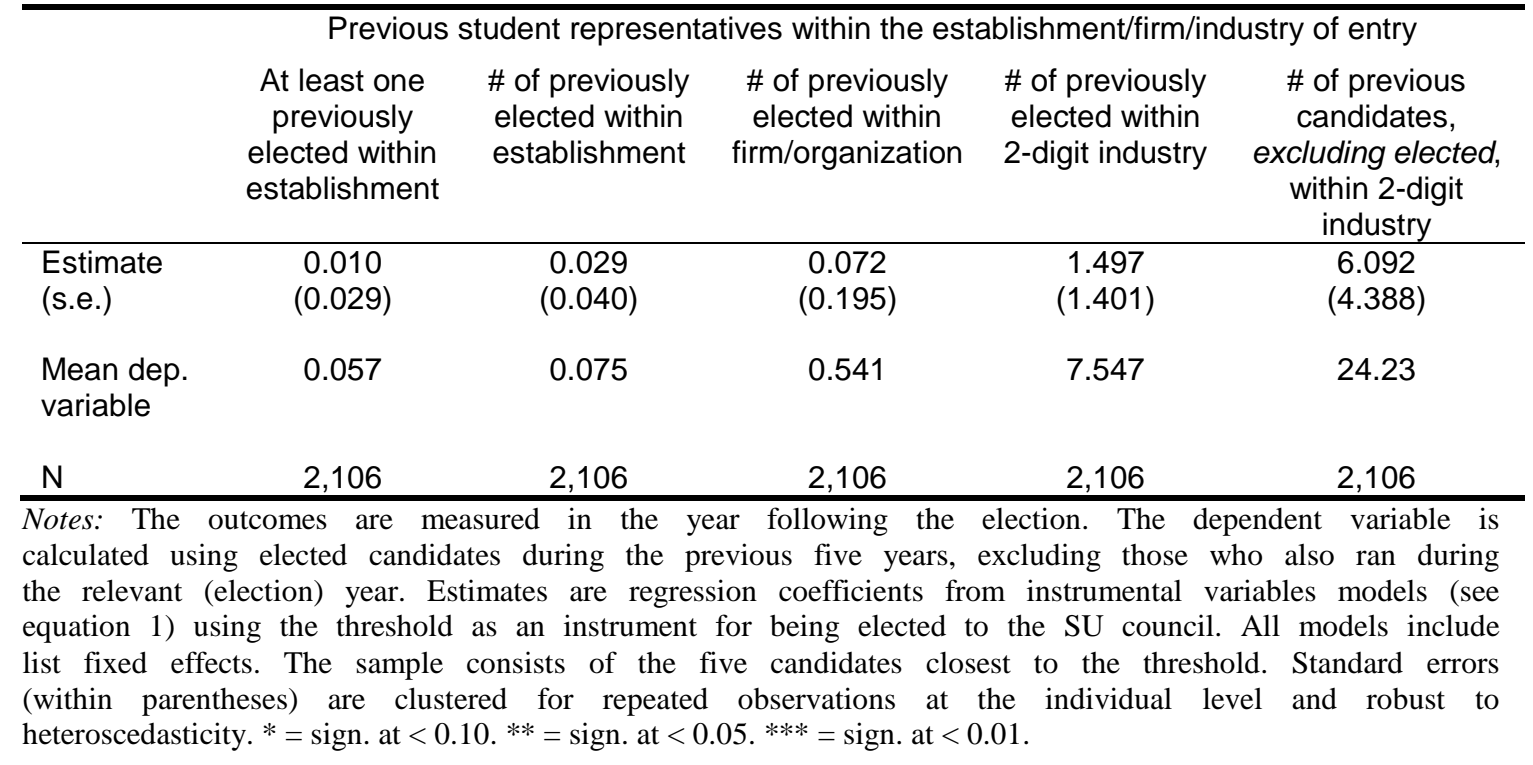

\subsection{Early career trajectories}

The results above suggest that the effects on employment are large but transitory in nature as other students catch up within a few years. In order to study more long-term effects it is therefore necessary to pay attention to more ambitious career targets. We therefore proceed by estimating the impact on the probability of finding a well-paid job, which we proxy by a dummy for earning at least as much as the median 30-year-old with a college education during that particular year. As our students on average are 24 years old when they run for the councils, it takes time to reach this target in most cases.

In the analysis, we let the dummy for holding a well-paid job replace employment as the outcome and repeat the analysis of the previous subsection. Figure 6 shows the impact using the same time interval as for labor market entry in Figure 4 above. The analysis generates a similar temporary effect as for employment, but two years later. Serving as a student representative has a significant impact on the probability of holding a well-paid job three years after the election. Thus, SU council experience is useful for getting a job one year after the SU election, and also for holding a well-paid job three

\footnotetext{
${ }^{19}$ To verify our conclusions, we have also estimated whether the students end up in universities or in NGOs, but again found no significant effects.
} 
years thereafter. But as with employment, the effect appears to wear off as other students catch up.

Figure 6 The effect of being elected to a SU council on the probability of holding a wellpaid job

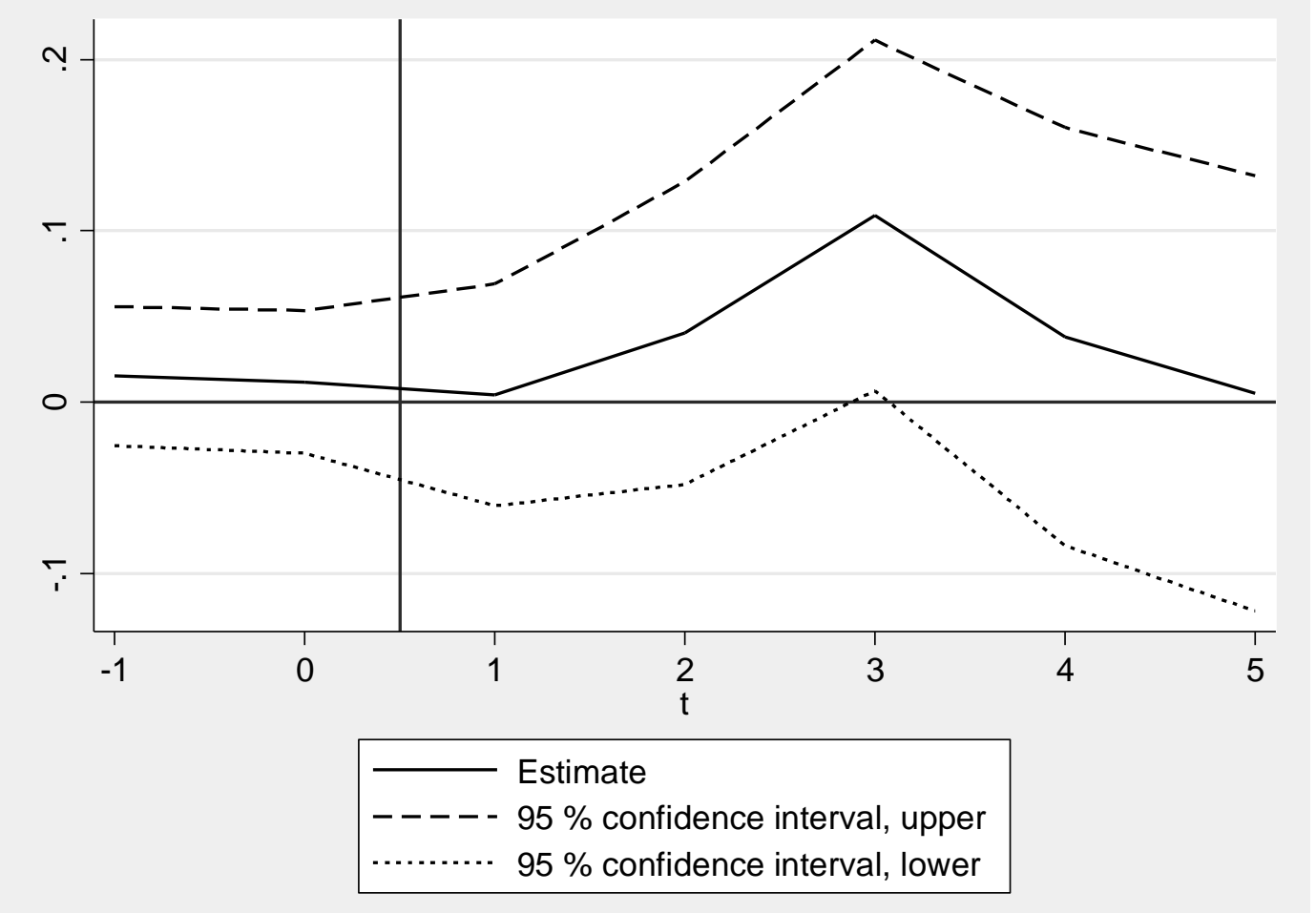

Notes: The figure depicts regression coefficients (and $95 \%$ confidence intervals) from instrumental variables models (see equation 1 ) from $t-1$ to $t+5$, where $t$ is the year when the student participated in the SU council elections. The Yaxis indicates estimates of how the probability of being employed in a well-paid job (above the $50^{\text {th }}$ percentile of earnings among college-educated 30-year-olds) changes if the student gets elected. $X$-axis: years relative to year of election $(t=0)$.

In Table 7, we show that the effect during the third year is stable across the same set of variations as in the previous subsection. ${ }^{20}$ We have also explored specifications using an even higher earnings threshold (the $75^{\text {th }}$ percentile) as the outcome in order to see whether the impact continues to be important, but at even higher levels (see Table A 2). Since virtually no students achieve this earnings level within less than three years after the election, we then focus on a slightly later time period: three to eight years after (the impact is insignificant in the years before for obvious reasons). The effects are statistically insignificant throughout when using our baseline model. However, there are some indications of a positive impact during year 5, but the effect appears to decline

\footnotetext{
${ }^{20}$ Figures for the nonparametric reduced form relationship for the third year and corresponding estimates for all bandwidths are shown in Figure A 6.
} 
thereafter. ${ }^{21}$ Overall, we interpret the evidence as suggesting that the positive impact lasts beyond the initial employment stage, but that the impact appears to wear off over time.

Table 7 The impact of being elected to a SU council on holding a well-paid job after three years: robustness

\begin{tabular}{lcccccc}
\hline & 1 & 2 & 3 & 4 & 5 & 6 \\
\hline Estimate & $0.109^{\star \star}$ & $0.116^{\star \star}$ & $0.109^{\star \star}$ & $0.200^{\star}$ & $0.175^{\star \star}$ & 0.085 \\
$($ s.e. $)$ & $(0.054)$ & $(0.054)$ & $(0.052)$ & $(0.104)$ & $(0.074)$ & $(0.056)$ \\
\hline $\mathrm{N}$ & 2,139 & 2,139 & 2,139 & 2,139 & 1,441 & 532 \\
Sample, closest: & 5 & 5 & 5 & 5 & 3 & 1 \\
Covariates & No & No & Yes & Yes & Yes & Yes \\
Ranking & Yes & Yes & Yes & Yes & Yes & No \\
$\begin{array}{l}\text { Ranking*above } \\
\text { threshold }\end{array}$ & No & Yes & Yes & Yes & Yes & No \\
Quadratic terms & No & No & No & Yes & No & No \\
\hline
\end{tabular}

Notes: Estimates are from instrumental variables models (see equation 1) using the threshold as an instrument for being elected to the SU council. Standard errors (within parentheses) are clustered for repeated observations at the individual level and robust to heteroscedasticity. $*=$ sign. at $<0.10$. $* *=$ sign. at $<0.05$. $* * *=$ sign. at $<0.01$.

Table 8 The impact of being elected to a SU council on Ln(Earnings)

\begin{tabular}{lccc}
\hline & \multicolumn{3}{c}{ Impact on In(Earnings) before and after } \\
& 1-2 years before & 1-3 years after & 4-6 years after \\
\hline Estimate & 0.061 & $0.336^{\star \star}$ & -0.061 \\
$($ s.e.) & $(0.178)$ & $(0.148)$ & $(0.144)$ \\
& & & 1,870 \\
$\mathrm{~N}$ & 1,622 & 2,045 & 5 \\
Sample, closest: & 5 & 5 & Yes \\
Covariates & Yes & Yes & Yes \\
Ranking & Yes & Yes & Yes \\
Ranking*above threshold & Yes & Yes & No \\
Quadratic terms & No & No & No
\end{tabular}

Notes: Estimates are from instrumental variables models (see equation 1) using the threshold as an instrument for being elected to the SU council. All models include list fixed effects. The sample consists of the five candidates closest to the threshold. Standard errors (within parentheses) are clustered for repeated observations at the individual level and robust to heteroscedasticity. $*=$ sign. at $<0.10$. $* *=$ sign. at $<0.05$. $* * *=$ sign. at $<0.01$.

As a final analysis, aiming to validate the conclusion regarding earnings trajectories, we have used log annual labor earnings as the dependent variable instead of the dummy for holding a (well-paid) job. In order to increase precision, and to avoid having to deal with zero-earnings cases, we have performed the analysis for three-year averages. We find a large impact on log earnings during the three years after the election, but

\footnotetext{
${ }^{21}$ In the appendix, we also show that the estimates after five years are statistically significant in some of the tighter specifications (Table A 2) and display the nonparametric relationship during the fifth year (Figure A 4).
} 
insignificant differences in the periods before and after that (Table 8). These results thus support the findings of our analysis on early career trajectories above. ${ }^{22}$

\subsection{Alternative outcomes}

\subsubsection{Academic performance}

The labor market benefits we have documented above measure the net effect of being elected to the SU councils. This could potentially mask an attenuating effect through reduced academic performance, which in turn may affect the labor market outcomes. Furthermore, it is possible that this explains the short-term nature of the effects if the (presumed) negative impacts on academic performance affect individuals' careers later in life. In order to investigate this issue, we study indicators of academic performance. Unfortunately, our performance indicators are not ideal; in particular, we lack data on grades. $^{23}$ Instead, we measure average annual credit-point production (scaled by the official metric of full-time studies). The sample is smaller since these data are only available from 1993 to 2009 . We estimate the model separately for two-year intervals starting in the year of the relevant election. The results are reported in Table 9.

Although the point estimates suggest a tendency for reduced study pace during the first few years, the estimates are statistically insignificant and fairly small (5 percent of full-time studies). In the last period (years $4-5$ ), the point estimate turns positive, but is even smaller. As a consequence, we conclude that the short-term nature of the main results is unlikely to be due to reduced academic performance.

\subsubsection{Political careers}

In Lundin et al. (2015), we examined the impact of SU experiences on future political careers in great detail using the same data and empirical setup as in this paper. Here, we provide a brief account of these results and relate them to the results we present in this paper. A first question of particular interest is whether the results are related in the sense that the earnings effects are driven by monetary rewards provided by success in the political arena. We believe that this is highly unlikely. As Lundqvist (2013) shows, the monetary rewards for participation in local Swedish politics (which, for natural reasons,

\footnotetext{
${ }^{22}$ See the appendix for robustness checks of the estimate in the mid column (Table A 3) and for a graphical presentation of the main results (Figure A 5).

${ }^{23}$ Swedish universities use very idiosyncratic grading metrics (using letters, numbers, or phrases) and grades are, to the best of our knowledge, not collected centrally at all. The grading metrics vary even across fields within the same university.
} 
make up most of the effect on political careers) are essentially zero. Although the effects we uncover in Lundin et al. (2015) are dramatic in relative terms (an increase by about 30 percent in participation as a candidate in regular politics), it still relates to a fairly small part of the overall sample. The effects imply a 6 percentage point increase in the probability that SU candidates will take part in regular politics at some future point. About one third of these get elected. Thus, responses along this margin are unlikely to explain the very large (transitory) career gains we document.

Table 9 The impact of being elected to a SU council on academic performance and political careers

\begin{tabular}{|c|c|c|c|c|c|}
\hline & \multicolumn{3}{|c|}{ Credit points (as fraction of full time) } & \multicolumn{2}{|c|}{ Public elections candidacies } \\
\hline & Year 0-1 & Year 2-3 & Year 4-5 & $\begin{array}{c}\text { Year 0-3 } \\
\text { (1st election cycle) }\end{array}$ & $\begin{array}{c}\text { Year 4-7 } \\
\text { (2nd election cycle) }\end{array}$ \\
\hline $\begin{array}{l}\text { Estimate } \\
\text { (s.e.) }\end{array}$ & $\begin{array}{l}-0.088 \\
(0.067)\end{array}$ & $\begin{array}{l}-0.075 \\
(0.049)\end{array}$ & $\begin{array}{c}0.030 \\
(0.040)\end{array}$ & $\begin{array}{c}0.015 \\
(0.018)\end{array}$ & $\begin{array}{l}0.044^{\star \star} \\
(0.018)\end{array}$ \\
\hline $\mathrm{N}$ & 1,363 & 1,363 & 1,279 & 1,684 & 2,116 \\
\hline Mean dep var & 0.664 & 0.308 & 0.159 & 0.117 & 0.103 \\
\hline Sample, closest: & 5 & 5 & 5 & 5 & 5 \\
\hline Covariates & Yes & Yes & Yes & Yes & Yes \\
\hline Lagged pol. cand. & No & No & No & Yes & Yes \\
\hline Ranking & Yes & Yes & Yes & No & No \\
\hline $\begin{array}{l}\text { Ranking*above } \\
\text { threshold }\end{array}$ & Yes & Yes & Yes & No & No \\
\hline Quadratic terms & No & No & No & No & No \\
\hline
\end{tabular}

Notes: Estimates are from instrumental variables models (see equation 1) using the threshold as an instrument for being elected to the SU council. All models include list fixed effects. The sample consists of the five candidates closest to the threshold. The model in the final two columns controls for lagged political candidacies but does not control for rank slopes. This is the preferred model used in Lundin et al. (2015). Standard errors (within parentheses) are clustered for repeated observations at the individual level and robust to heteroscedasticity. $*=$ sign. at $<0.10$. ** $=$ sign. at $<0.05 . * * *$ sign. at $<0.01$.

In the last two columns of Table 9, we repeat the analysis of Lundin et al. (2015) for the first two (four-year) election cycles after the student union elections, showing a significant (but small, relative to the impact on employment) effect for the second cycle. ${ }^{24}$ Further results provided by Lundin et al. (2015) also suggest that the impact on political candidacy is much more persistent than the labor market outcomes we document in this paper, suggesting that the mechanisms underlying the two processes are different.

\footnotetext{
${ }^{24}$ We do not have data for the earliest election years, explaining the smaller sample size for the first election cycle.
} 


\section{Conclusions}

In this paper, we have examined the impact of acquiring leadership experiences during college years on labor market entry and early career trajectories. Relying on an RD approach using combined archive and register data, we add to a very scarce set of papers that have been able to provide credible evidence of how leadership experiences prior to labor market entry affect economic outcomes.

The results show that becoming a student representative causally increases the probability of a rapid transition to work. The probability of being employed one year after participating in a SU election increases by about 0.2 from a baseline of 0.45 if a candidate manages to get elected. The impact is found to be robust to a wide set of modifications of the RD model. This effect is not confined to segments (workplaces, firms, or industries) of the labor market where previous representatives are employed, suggesting that the benefits are general in nature. We also show that the effects appear to be somewhat larger among students who lack prior work experience, which indicates that participating in leadership activities within the councils serves as a substitute for working during college years. Furthermore, elected representatives are more likely to hold a well-paid job within three years. However, although our findings suggest that the initial career trajectories are enhanced by a positive election outcome, the effects do not appear to be permanent. Instead, students who fail to be elected are able to catch up within a few years.

The research design and our data do not allow us to provide a clear-cut conclusion on exactly why leadership activities during college affect labor market outcomes. Conceptually, participation in the councils may help students to accumulate leadership skills, signal preexisting non-cognitive skills, and generate useful labor market networks. However, we cautiously suggest that the evidence is most readily reconciled with an interpretation in terms of signaling. In particular, we note that the impact is short-lived and, as argued in the employer learning literature, the value of an initial signal should decrease as workers accumulate labor market experience. ${ }^{25}$ The time profile of the effects is also well in line with the learning estimates provided by Lange (2007). Along the same lines, the results appear stronger among students who lack

\footnotetext{
${ }^{25}$ Note that the RD analysis explicitly compares students who receive different signals despite being equally skilled ex ante. See Feng and Graetz (2013) for an explicit analysis of signaling effects during labor market entry after college using an RD design.
} 
previous work experience. We also note that the fact that the impact appears to be widely dispersed across different industries and firms suggests that the signals work beyond the immediate network generated through the councils.

Regardless of the underlying mechanisms, our main conclusion does, however, convey an important message: Acquiring leadership experiences prior to labor market entry may turn out to be a useful investment since these activities provide youths with a kick-start in their careers. This finding also highlights the need for expanding the research literature on the transition from school to work to include the role of other potential signals of non-cognitive skills. 


\section{References}

Altonji, J. G. and C. R. Pierret (2001), "Employer learning and statistical discrimination”, Quarterly Journal of Economics, 116(1), 313-350.

Arcidiacono, P., P. Bayer and A. Hizmo (2010), "Beyond signaling and human capital: Education and the revelation of ability”, American Economic Journal: Applied Economics, 2(4), 76-104.

Barron, J. M., B. T. Ewing and G. R. Waddell (2000), "The effects of high school athletic participation on education and labor market outcomes”, Review of Economics and Statistics, 82(3), 409-421.

Becker, G. S. (1964), Human Capital: A Theoretical and Empirical Analysis, with Special Reference to Education, Chicago \& London: The University of Chicago Press.

Eide, E. R. and N. Ronan (2001), "Is participation in high school athletics an investment or a consumption good?: Evidence from high school and beyond”, Economics of Education Review, 20(5), 431-442.

Farb, A. F. and J. L. Matjasko (2012), "Recent advances in research on school-based extracurricular activities and adolescent development”, Developmental Review, 32(1), 1-48.

Feng, A. and G. Graetz (2013), “A question of degree: the effects of degree class on labor market outcomes”, in C. C. f. E. P. CEP Discussion Papers, London School of Economics and Political Science, London, UK (Ed.).

Geel, R. and U. Backes-Gellner (2012), "Earning while learning: When and how student employment is beneficial”, Labour, 26(3), 313-340.

Grönqvist, E. and E. Lindqvist (2016), “The Making of a Manager: Evidence from Military Officer Training”, Journal of Labor Economics, 34(4).

Henderson, D. J., A. Olbrecht and S. W. Polachek (2006), “Do former college athletes earn more at work? A nonparametric assessment”, Journal of Human Resources, 41(3), 558-577. 
Hensvik, L. and O. N. Skans (2013), ”Hur arbetslivserfarenhet och nätverk kan förändra avkastningen på förmågor och utbildning”, Uppsala: Institute for Evaluation of Labour Market and Education Policy.

Hotz, V. J., L. C. Xu, M. Tienda and A. Ahituv (2002), “Are there returns to the wages of young men from working while in school?”, Review of Economics and Statistics, 84(2), 221-236.

Häkkinen, I. (2006), “Working while enrolled in a university: Does it pay?”, Labour Economics, 13(2), 167-189.

Klemenčič, M. (2012), "Student representation in Western Europe: introduction to the special issue”, European Journal of Higher Education, 2(1), 2-19.

Kotakorpi, K., P. Poutvaara and M. Terviö (2013), ”Returns to office in national and local politics”, CESifo Working Paper no 4542.

Kramarz, F. and O. N. Skans (2014), "When Strong Ties are Strong: Networks and Youth Labour Market Entry”, The Review of Economic Studies, doi: 10.1093/restud/ rdt1049rdt1049.

Kuhn, P. and C. Weinberger (2005), “Leadership skills and wages”, Journal of Labor Economics, 23(3), 395-436.

Lange, F. (2007), “The speed of employer learning”, Journal of Labor Economics, 25(1), 1-35.

Lee, D. S. and D. Card (2008), "Regression discontinuity inference with specification error”, Journal of Econometrics, 142(2), 655-674.

Lee, D. S. and T. Lemieux (2010), "Regression discontinuity designs in economics", Journal of Economic Literature, 48, 281-355.

Light, A. (2001), “In-school work experience and the returns to schooling”, Journal of Labor Economics, 19(1), 65-93.

Light, A. and A. McGee (2012), “Employer Learning and the 'Importance' of Skills”, IZA Discussion Papers 6623, Institute for the Study of Labor (IZA). 
Lipscomb, S. (2007), "Secondary school extracurricular involvement and academic achievement: A fixed effects approach”, Economics of Education Review, 26(4), $463-472$.

Lozano, F. A. (2008), “Language, high school leadership and the postsecondary outcomes of Hispanic students”, Economics of Education Review, 27(3), 342-353.

Lundin, M., O. N. Skans and P. Zetterberg (2015), “Leadership Experiences Within Civil Organizations and Candidacy in Public Elections: Causal Evidence from a Quasi-Experimental Approach”, Political Behavior, doi: 10.1007/s11109-1101519320-x.

Lundqvist, H. (2013), "Is it worth it? On the returns to holding political office", IEB Working Paper N. 2013/014

Rees, D. I. and J. J. Sabia (2010), "Sports participation and academic performance: Evidence from the National Longitudinal Study of Adolescent Health”, Economics of Education Review, 29(5), 751-759.

Roulin, N. and A. Bangerter (2013), "Students' use of extra-curricular activities for positional advantage in competitive job markets”, Journal of Education and Work, 26(1), 21-47.

Rouse, K. E. (2012), “The Impact of High School Leadership on Subsequent Educational Attainment”, Social Science Quarterly, 93(1), 110-129.

Shue, K. (2013), "Executive networks and firm policies: Evidence from the random assignment of MBA peers”, Review of Financial Studies, 26(6), 1401-1442.

Spence, M. (1973), “Job market signaling”, The Quarterly Journal of Economics, 355374.

Stevenson, B. (2010), “Beyond the classroom: Using Title IX to measure the return to high school sports”, Review of Economics and Statistics, 92(2), 284-301.

Stinebrickner, R. and T. R. Stinebrickner (2003), "Working during school and academic performance”, Journal of Labor Economics, 21(2), 473-491. 
Thistlethwaite, D. L. and D. T. Campbell (1960), "Regresion-Discontinuity Analysis: An Alternative to the Ex Post Facto Experiment”, Journal of Educational Psychology, 51(6), 309-317. 


\section{Appendix - additional tables and figures}

Table A 1 Number of observations by year and university

\begin{tabular}{lrrrrr}
\hline Year & Lund & Stockholm & Uppsala & Total & Average/year \\
\hline 1982 & 0 & 0 & 182 & 182 & 182 \\
1983 & 0 & 0 & 0 & 0 & 0 \\
$1984-1990$ & 1,467 & 0 & 0 & 1,467 & 210 \\
$1991-1993$ & 606 & 0 & 0 & 606 & 202 \\
1994 & 0 & 0 & 0 & 0 & 0 \\
$1995-1996$ & 0 & 417 & 0 & 417 & 209 \\
$1997-2004$ & 0 & 1,277 & 1,079 & 2,356 & 295 \\
2005 & 0 & 126 & 0 & 126 & 126 \\
$2006-2010$ & - & - & - & - & - \\
\hline Total & 2,073 & 1,820 & 1,261 & 5,154 & 215 \\
\hline
\end{tabular}

Note: We group years when data availability was equal during multiple subsequent years.

Table A 2 The effects on high wage employment (above 75th) five years after: robustness

\begin{tabular}{lcccccc}
\hline & 1 & 2 & 3 & 4 & 5 & 6 \\
\hline Estimate & 0.076 & 0.077 & 0.069 & $0.177^{\star}$ & 0.118 & $0.106^{\star}$ \\
$($ s.e $)$ & $(0.054)$ & $(0.054)$ & $(0.053)$ & $(0.102)$ & $(0.076)$ & $(0.059)$ \\
\hline $\mathrm{N}$ & 2,028 & 2,028 & 2,028 & 2,028 & 1,365 & 504 \\
Sample, closest: & 5 & 5 & 5 & 5 & 3 & 1 \\
Covariates & No & No & Yes & Yes & Yes & Yes \\
Ranking & Yes & Yes & Yes & Yes & Yes & No \\
$\begin{array}{l}\text { Ranking*above } \\
\text { threshold }\end{array}$ & No & Yes & Yes & Yes & Yes & No \\
Quadratic terms & No & No & No & Yes & No & No \\
\hline
\end{tabular}

Notes: Estimates are from instrumental variables models (see equation 1) using the threshold as an instrument for being elected to the SU council. All models include list fixed effects. Standard errors (within parentheses) are clustered for repeated observations at the individual level and robust to heteroscedasticity. $*=$ sign. at $<0.10$. ${ }^{* *}=$ sign. at $<0.05$. $* * *=$ sign. at $<0.01$.

Table A 3 The effects on log earnings one to three years after: robustness

\begin{tabular}{lcccccc}
\hline & 1 & 2 & 3 & 4 & 5 & 6 \\
\hline Estimate & $0.336^{\star \star}$ & $0.367^{\star \star}$ & $0.336^{\star \star}$ & 0.429 & $0.387^{\star}$ & 0.234 \\
$($ s.e. $)$ & $(0.151)$ & $(0.154)$ & $(0.148)$ & $(0.294)$ & $(0.210)$ & $(0.170)$ \\
\hline $\mathrm{N}$ & 2,045 & 2,045 & 2,045 & 2,045 & 1,376 & 508 \\
Sample, closest: & 5 & 5 & 5 & 5 & 3 & 1 \\
Covariates & No & No & Yes & Yes & Yes & Yes \\
Ranking & Yes & Yes & Yes & Yes & Yes & No \\
Ranking*above & No & Yes & Yes & Yes & Yes & No \\
threshold & No & No & No & Yes & No & No \\
Quadratic terms & No & & & & & \\
\hline
\end{tabular}

Notes: Estimates are from instrumental variables models (see equation 1) using the threshold as an instrument for being elected to the SU council. All models include list fixed effects. Standard errors (within parentheses) are clustered for repeated observations at the individual level and robust to heteroscedasticity. ${ }^{*}=$ sign. at $<0.10$. $* *=$ sign. at $<0.05$. $* * *=$ sign. at $<0.01$. 
Figure A 1 The number of observations by rank relative to the threshold

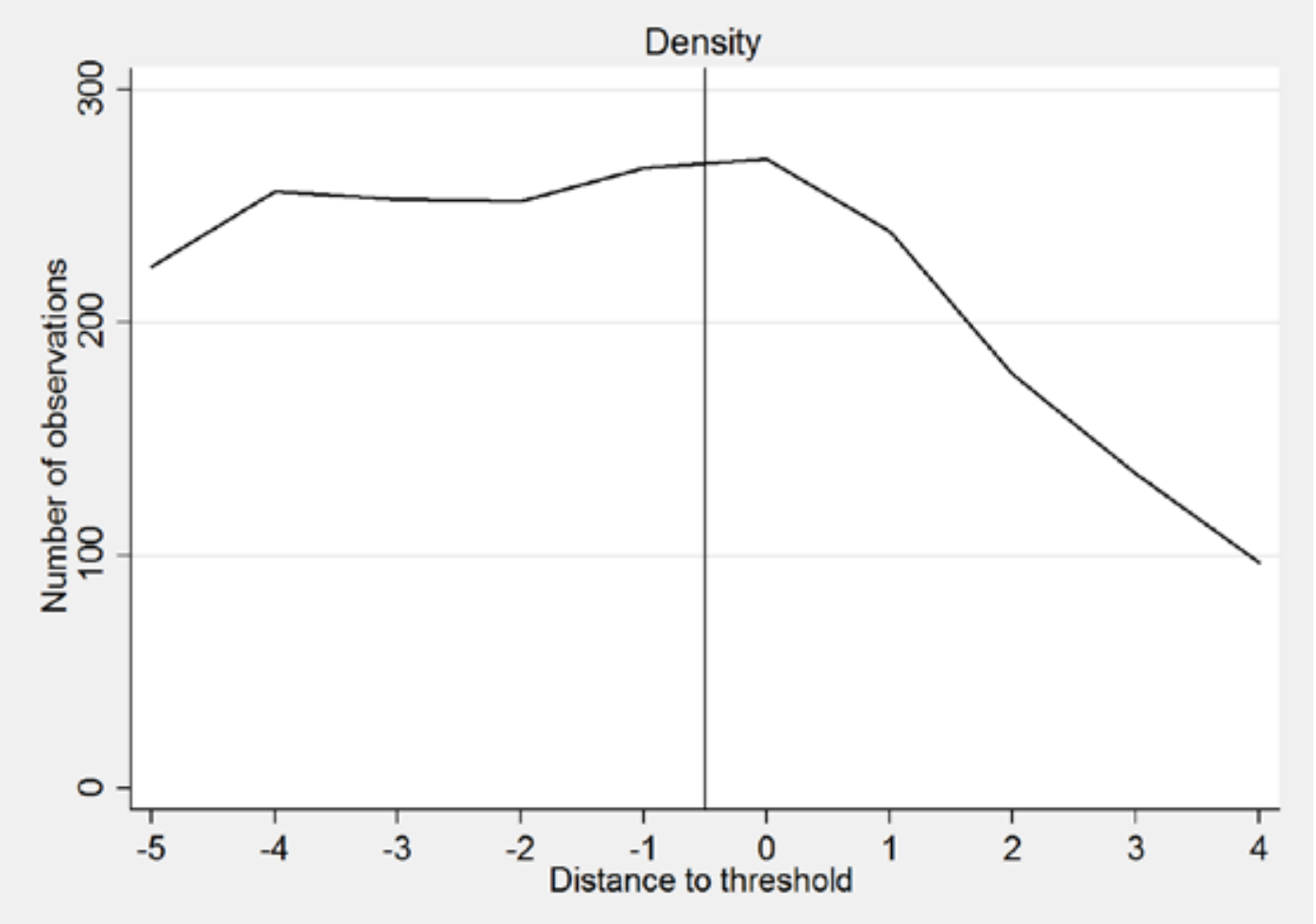

Figure A 2 Reduced form relationship between list rankings and the probability of holding a well-paid job (median) after three years

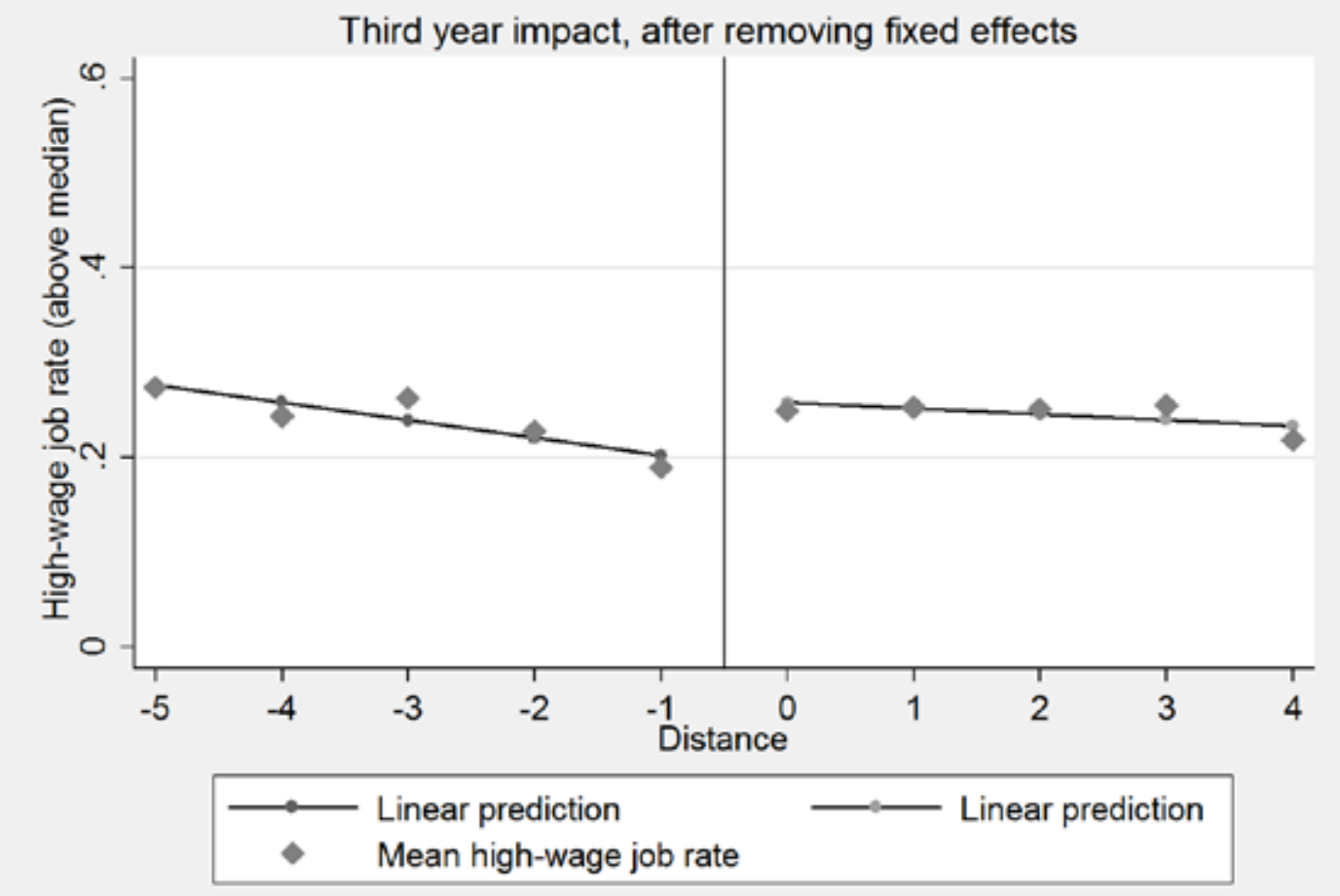


Figure A 3 The impact on the probability of holding a well-paid job (above $75^{\text {th }}$ percentile)

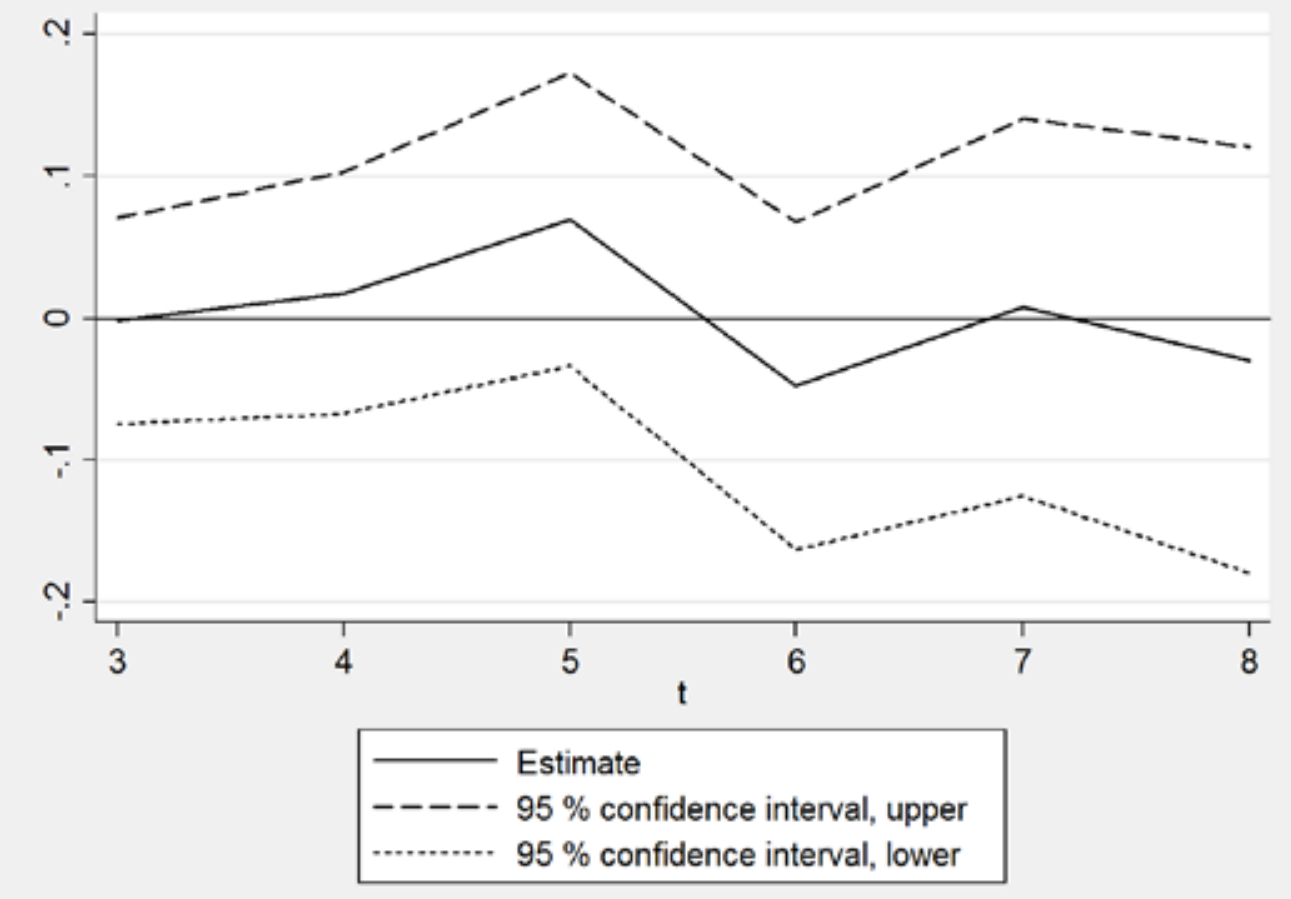

Figure A 4 Reduced form relationship between list rankings and the probability of holding a well-paid job (above $75^{\text {th }}$ percentile) after five years

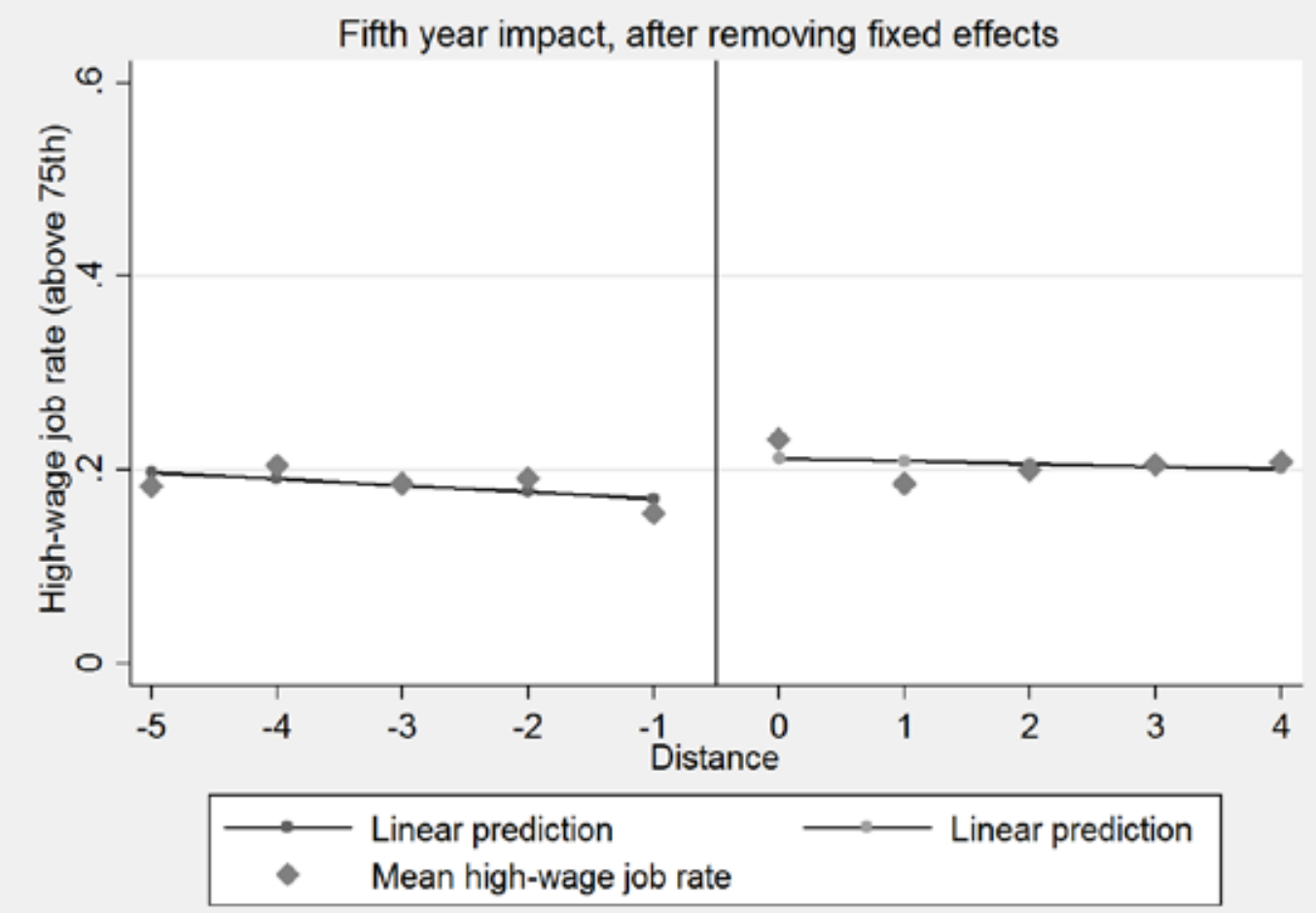


Figure A 5 Reduced form relationship between list rankings and In(Earnings) one to three years after

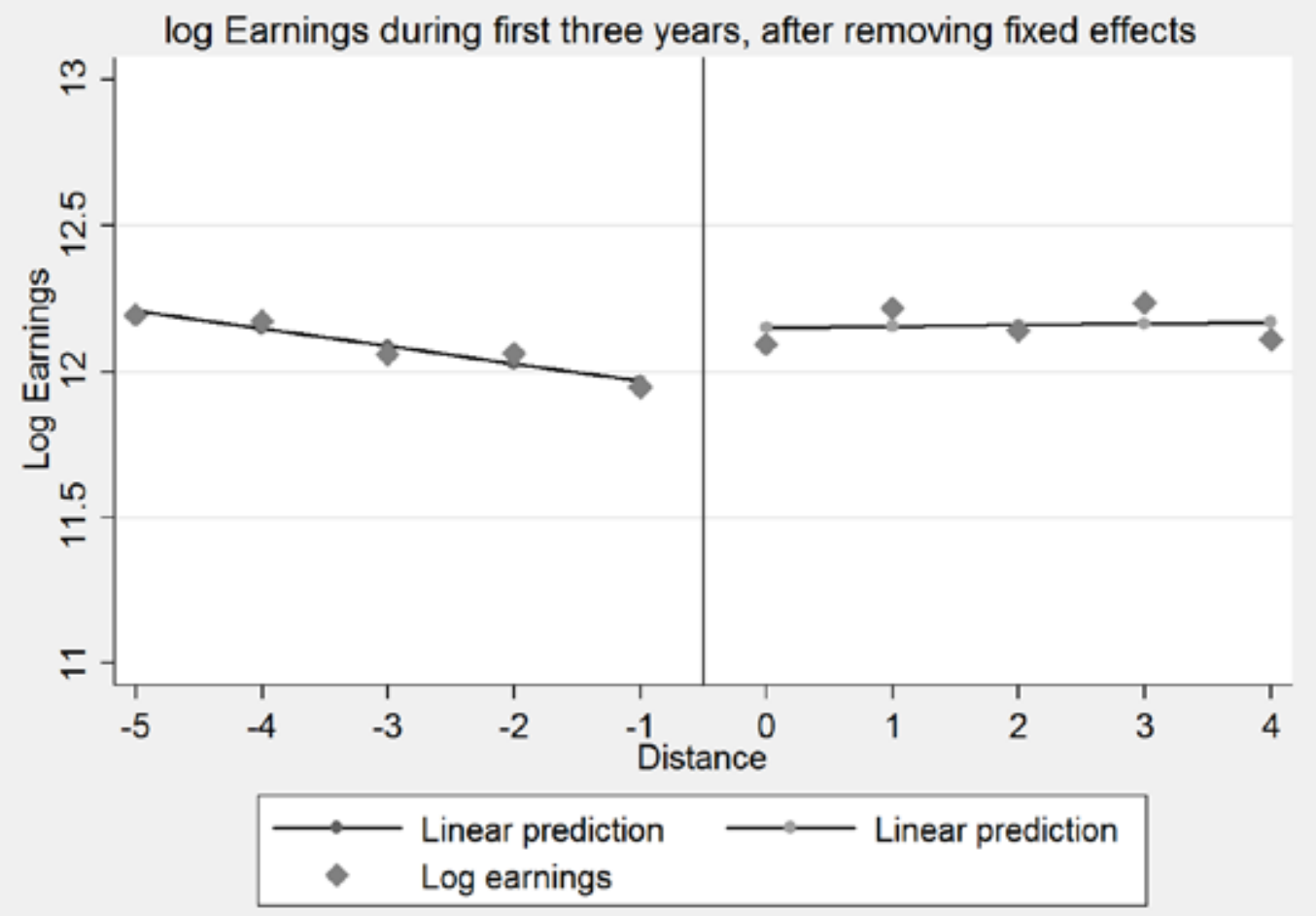

Figure A 6 Estimates for different bandwidths for the probability of being employed year 1 and the probability of holding a well-paid job after three years
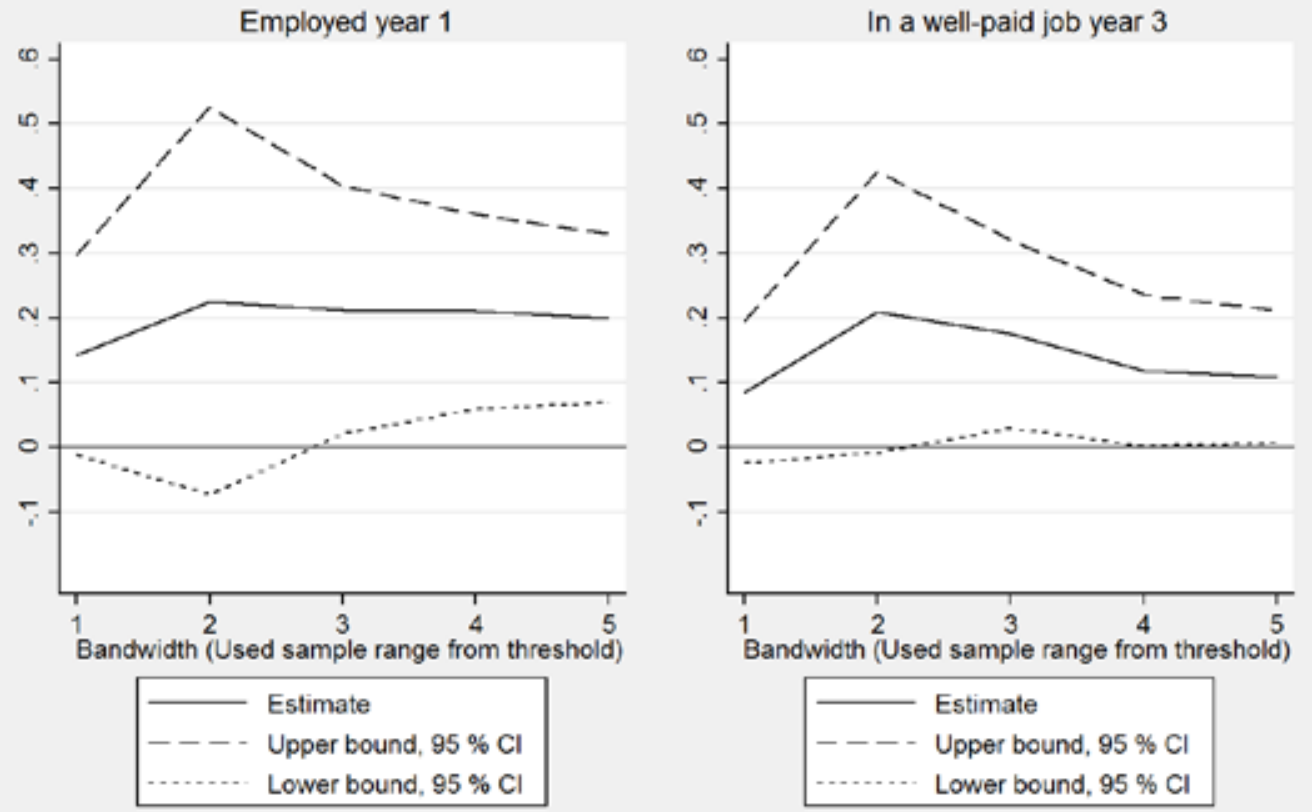

Note: All regressions control for age, gender, origin, study time,

prev. employment and SU experience. Rank controls (above vs below) if BW>1.

Standard errors are clustered by individuals. 
Figure A 7 The impact of becoming a student union representative on employment up to five years after SU council elections, excluding subsequent winners

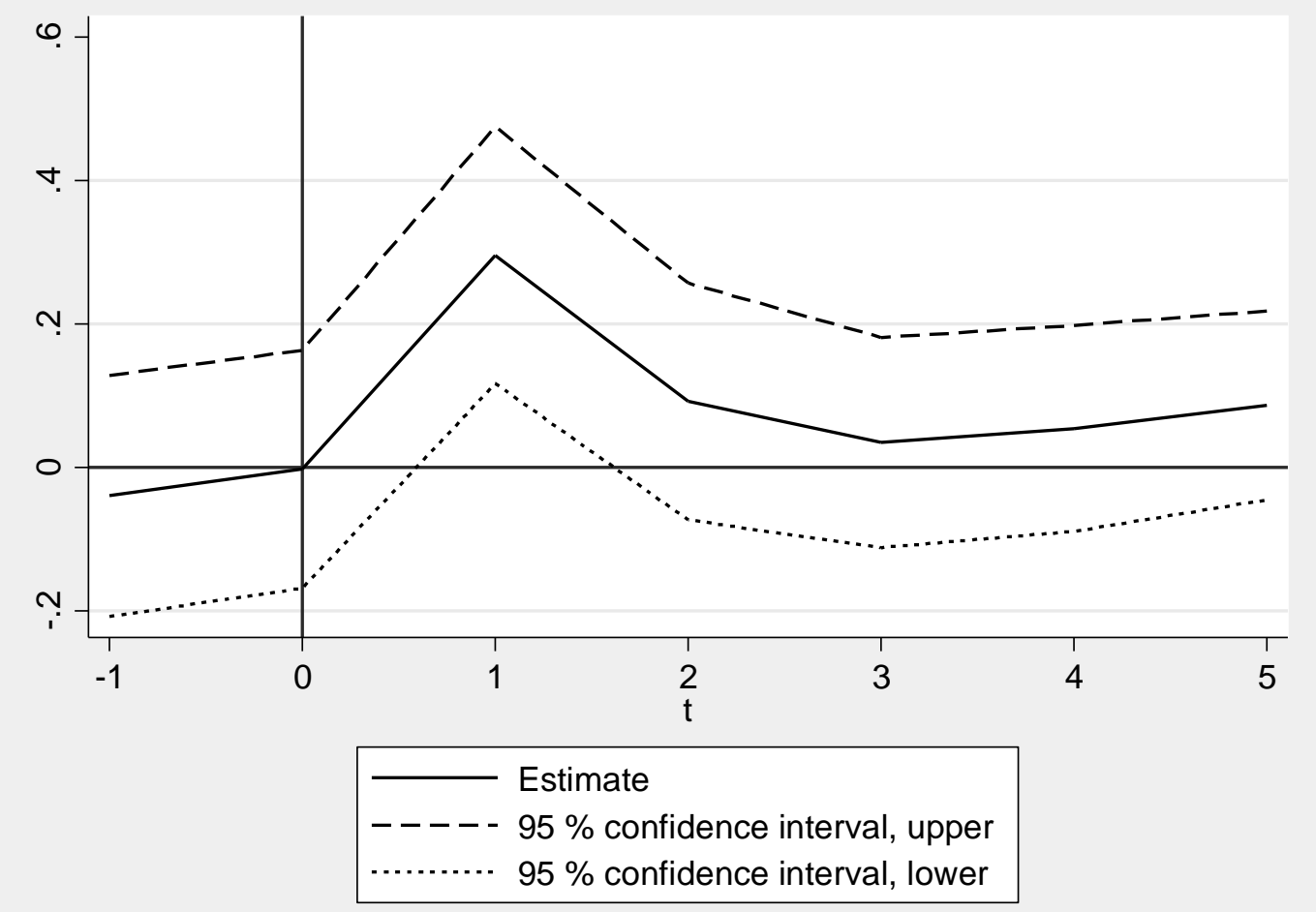




\section{Publication series published by IFAU - latest issues}

\section{Rapporter/Reports}

2015:20 Fredriksson Peter, Lena Hensvik and Oskar Nordström Skans ” Rätt man på rätt plats? Matchning, ingångslöner och separationer"

2015:21 Fredriksson Peter, Hessel Oosterbeek and Björn Öckert ”Hur reagerar föräldrar på resursneddragningar i skolan?”

2015:22 Hensvik Lena and Olof Rosenqvist "Sjukfrånvaro och anställningar till unika positioner"

2015:23 Assadi Anahita, Caroline Hall, Martin Lundin and Kristina Sibbmark "Erfarenheter och effekter av satsningar på lärare i skolor med låga elevresultat"

2015:24 Johansson Per, Lisa Laun and Mårten Palme "Kan vi jobba tills vi blir 75? Vad säger mikrodata om hälsa och arbetskapacitet bland de äldre i arbetskraften?"

2015:25 Vikström Johan "Effekter av sekvenser av arbetsmarknadspolitiska program”

2016:1 Engdahl Mattias and Anders Forslund ”En förlorad generation? Om ungas etablering på arbetsmarknaden"

2016:2 Bastani Spencer, Ylva Moberg and Håkan Selin ”Hur känslig är gifta kvinnors sysselsättning för förändringar i skatte- och bidragssystemet?”

2016:3 Lundin Martin, Oskar Nordström Skans and Pär Zetterberg ”Kåren och karriären: Studentpolitiken som språngbräda”

\section{Working papers}

2015:20 Stadin Karolina "Firms' employment dynamics and the state of the labor market"

2015:21 Öhman Mattias "Be smart, live long: the relationship between cognitive and non-cognitive abilities and mortality"

2015:22 Hägglund Pathric, Per Johansson and Lisa Laun "Rehabilitation of mental illness and chronic pain - the impact on sick leave and health"

2015:23 Mellander Erik and Joakim Svärdh "Inquiry-based learning put to test: long-term effects of the Swedish science and technology for children program"

2015:24 Norén Anna "Childcare and the division of parental leave"

2015:25 Åslund Olof, Ina Blind and Matz Dahlberg "All aboard? Commuter train access and labor market outcomes"

2015:26 Fredriksson Peter, Lena Hensvik and Oskar Nordström Skans "Mismatch of talent: evidence on match quality, entry wages, and job mobility"

2015:27 Fredriksson Peter, Hessel Oosterbeek and Björn Öckert "Parental responses to public investments in children: evidence from a maximum class size rule"

2015:28 Hensvik Lena and Olof Rosenqvist "The strength of the weakest link: sickness absence, internal substitutability and worker-firm matching"

2015:29 Johansson Per, Lisa Laun and Mårten Palme "Health, work capacity and retirement in Sweden"

2016:1 Bastani Spencer, Ylva Moberg and Håkan Selin "Estimating participation responses using transfer program reform"

2016:2 Lundin Martin, Oskar Nordström Skans and Pär Zetterberg ”Leadership experiences, labor market entry,and early career trajectories"

\section{Dissertation series}

2015:1 Egebark Johan "Taxes, nudges and conformity. Essays in labor and behavioral economics"

2015:2 Blind Ina "Essays on urban economics" 